\title{
Palladium-Catalysed Construction of All-Carbon Quaternary Centres with Propargylic Electrophiles: Challenges in the Simultaneous Control of Regio-, Chemo- and Enantioselectivity
}

\author{
Miles Kenny ${ }^{a}$ \\ Sybrin P. Schröder \\ Nicholas J. Taylor ${ }^{b}$ \\ Paula Jackson ${ }^{\mathrm{b}}$ \\ Daniel J. Kitson ${ }^{\text {a }}$ \\ Vilius Franckevičius*a \\ ${ }^{a}$ Department of Chemistry, Lancaster University, Lancaster \\ LA1 4YB, UK. \\ ${ }^{\mathrm{b}}$ Department of Chemistry, University of York, Heslington, \\ York YO10 5DD, UK. \\ * indicates the main/corresponding author \\ v.franckevicius@lancaster.ac.uk
}<smiles>[R]C(=O)/C([R])=C(/[R])OC(=O)OCC#C</smiles>

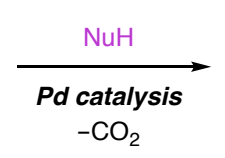

Challenges:
The simultaneous control of
• regioselectivity
• chemoselectivity
- enantioselectivity

\begin{abstract}
Received:
Accepted:
Publis

Abstract This article describes the palladium-catalysed three-component coupling of 1,3-dicarbonyl compounds with nucleophiles and propargylic electrophiles for the generation of quaternary all-carbon centres in a single step, which necessitates the simultaneous control of regio-, chemo- and enantioselectivity. The use of propargyl enol carbonates, the source of two of the components, was found to be essential in maintaining high levels of regiocontrol and chemoselectivity, whereas a careful analysis of $\mathrm{p} K_{\mathrm{a}}$ trends of $\mathrm{O}$-, $\mathrm{C}$ - and $\mathrm{N}$-nucleophiles as the other coupling partner indicates that the highest levels of selectivity are likely to be obtained with relatively acidic species, such as phenols, 1,3-dicarbonyl compounds and aromatic Nheterocycles. Finally, studies towards the development of the catalytic enantioselective construction of quaternary all-carbon centres by means of alkenylation and allylic alkylation are disclosed.
\end{abstract}

Key words Palladium, enantioselective catalysis, quaternary centres, propargylic electrophiles, 1,3-dicarbonyl compounds

To facilitate drug discovery programmes, the pharmaceutical industry has historically relied upon tapping into compound screening libraries which are strongly biased towards molecules that are rich in aromatic character and flat structural features. ${ }^{1}$ These properties are associated with low shape diversity, poorer solubility, higher toxicity and, therefore, higher levels of attrition during drug development. ${ }^{2}$ To alleviate this effect, there is currently a strong drive to enhance the efficiency of drug discovery processes by utilising molecules with greater 3D complexity, increased levels of saturation and more chiral centres. ${ }^{3}$ These changes can result in better solubility profiles, higher selectivity of binding and lower toxicity, ${ }^{4}$ as well as more efficient sampling of larger areas of chemical space. 5 Quaternary all-carbon centres inherently offer scope for maximal exploration of 3D chemical space through chain growth in all four directions from the $\mathrm{sp}^{3}$ tetrahedral carbon atom. However, quaternary all-carbon centres are severely sterically crowded, making the catalytic enantioselective construction of such centres a formidable synthetic challenge and an active area of research. ${ }^{6}$ As such, the development of new catalytic methodologies for the installation of quaternary centres remains essential towards enabling access to novel 3D building blocks for drug discovery.

Our group has had a long-standing interest in the reactivity of propargylic electrophiles under palladium catalysis, the broad reactivity profiles that propargylic electrophiles exhibit, and the opportunities to exploit this type of reactivity in the construction of quaternary all-carbon centres. In reactions with a palladium(0) catalyst (A, Scheme 1), propargylic electrophiles, such as carbonate $\mathbf{1}$, lead to the formation of $\eta^{3-}$ $\pi$-propargylpalladium(II) intermediate 2 via oxidative addition and subsequent decarboxylation. ${ }^{7}$ Although species $\mathbf{2}$ can take part in propargylation and allenylation reactions, 8 the process generating the most complexity is one that allows the coupling of two nucleophiles with $2 .{ }^{9}$ Such a process typically requires the use of soft nucleophiles, ${ }^{10}$ the first of which undergoes addition at the central carbon atom in $\mathbf{2}$ and affords transient palladacyclobutene species $\mathbf{3 . 1 1}$ Protonation of $\mathbf{3}$ by the conjugate acid of the second nucleophile gives rise to $\eta^{3}-\pi$ allylpalladium(II) intermediate $\mathbf{4}$, where the initial palladacyclobutene $\mathbf{3}$ formation and protonation may be synchronous. $^{7 \mathrm{~b}}$ In the final mechanistic step, allylic alkylation at one of the termini in $\mathbf{4}$ affords product $\mathbf{5}$, in which one nucleophile has undergone alkenylation and the second, allylic alkylation. Unfortunately, the direct one-pot coupling of $\eta^{3}-\pi$ propargylpalladium(II) intermediate 2 with two independent nucleophiles is extremely challenging owing to several selectivity issues (B, Scheme 1). ${ }^{12}$ Firstly, the order of addition of the two nucleophiles must be controlled so that only one of the two cross-coupled products $\mathbf{5}$ or $\mathbf{6}$ is made (regioselectivity). Secondly, homo-coupling of just one nucleophile, leading to $\mathbf{7}$ and $\mathbf{8}$, must also be prevented (chemoselectivity). 


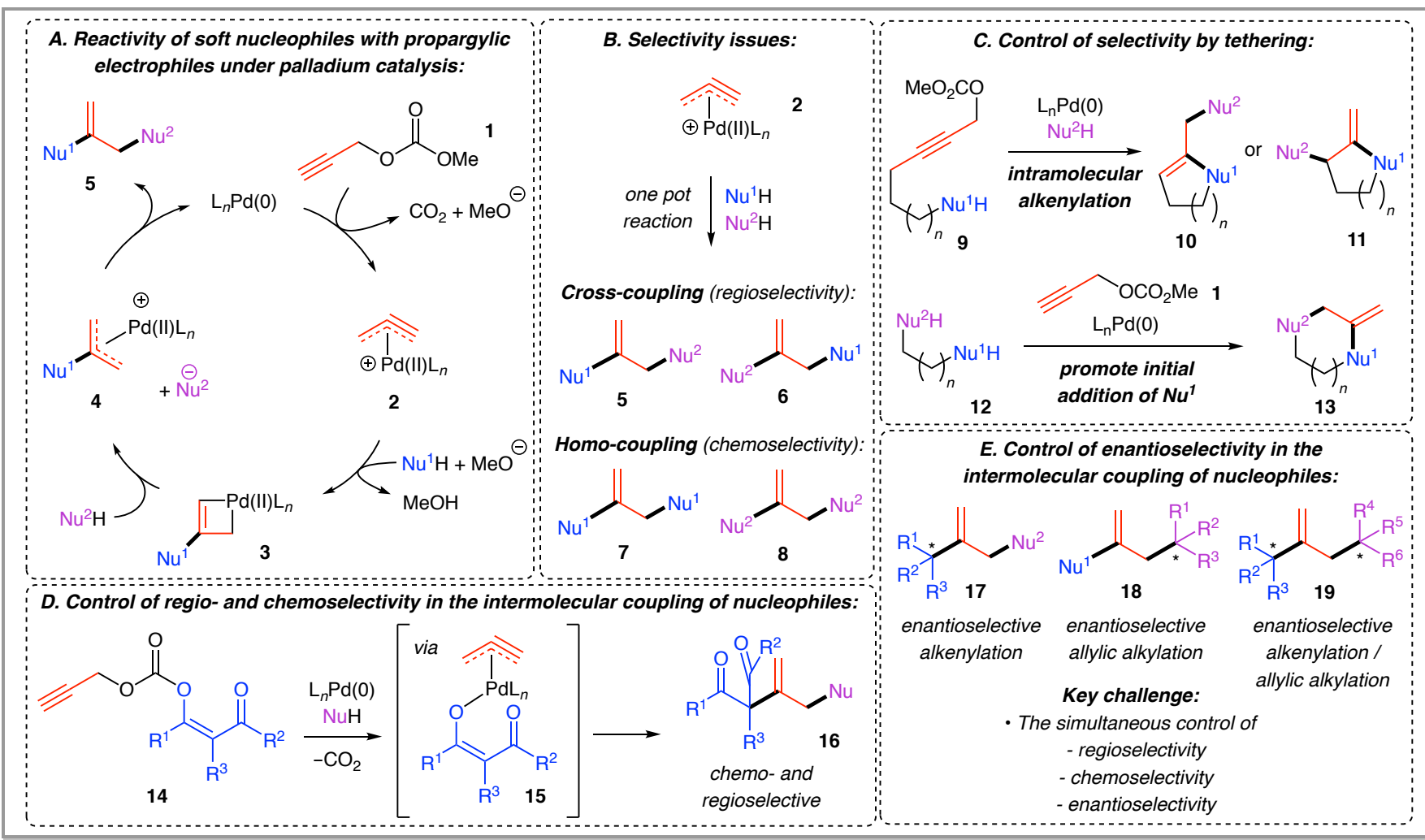

Scheme 1 Control of selectivity in palladium-catalysed coupling reactions of nucleophiles with propargylic electrophiles.

Typically, these selectivity challenges can be overcome by employing tethering strategies in cyclisation reactions (C, Scheme 1). For example, if one of the nucleophiles is tethered to the propargylic electrophile in 9,13 then alkenylation of the tethered nucleophile is likely to occur prior to alkenylation of the external nucleophile due to the intramolecular nature of the cyclisation reaction. Allylic alkylation of the second nucleophile then follows at either the less or the more substituted position to afford $\mathbf{1 0}$ or $\mathbf{1 1}$, respectively. An alternative approach is the use of tethered bis-nucleophiles 12. ${ }^{14}$ In such a process, a clear differentiation between the two nucleophiles in $\mathbf{1 2}$ must be achieved if the order of addition is to be accurately controlled. If one of the nucleophiles is more acidic than the other, then it should preferentially undergo the initial deprotonation and, therefore, alkenylation, followed by intramolecular allylic alkylation of the second nucleophile to afford 13. Alternatively, if the acidity is similar, a strong steric bias between the two nucleophiles or a distinct difference in nucleophilicity could favour the initial addition of one nucleophile over the other. Both approaches enable the control of regioselectivity, whereas homo-coupling is prevented through intramolecularity.

To exploit the use of palladium catalysis in the generation of quaternary all-carbon centres from propargylic electrophiles, our group discovered a method that enables the coupling of nucleophiles to afford linear products whilst maintaining high levels of regiocontrol and chemoselectivity. This approach involves the use of propargylic enol carbonates 14 (D, Scheme 1), derived from 1,3-dicarbonyl compounds. The palladiumcatalysed reaction proceeds via intermediate $\mathbf{1 5}$ following oxidative addition and decarboxylation, in which the $\eta^{3}-\pi$ -
propargylpalladium(II) electrophile remains tightly associated with the enolate nucleophile. ${ }^{15}$ This process results in the selective intramolecular alkenylation of the enolate and intermolecular allylic alkylation of the external nucleophile to afford linear products of type $\mathbf{1 6}$ with high regio- and chemoselectivity, in which a quaternary all-carbon centre has been installed. We surmised that, in the presence of a chiral ligand on palladium, the use of a non-symmetrical enolate could result in the enantioselective construction of a quaternary all-carbon centre in $\mathbf{1 7}$ via alkenylation (E, Scheme 1). Similarly, the use of a non-symmetrical external carbonbased nucleophile could lead to the enantioselective installation of a quaternary carbon centre by means of allylic alkylation (18). Finally, the use of two non-symmetrical carbon-based nucleophiles could, in principle, pave the way to the enantioselective construction of two all-carbon quaternary centres in a single step (19). However, to achieve both high efficiency and stereoselectivity in any of the above enantioselective processes, all control elements, namely, regio-, chemo- and enantioselectivity, must be simultaneously controlled. Indeed, there are very few examples reported of the enantioselective construction of quaternary all-carbon centres by means of alkenylation using the palladium-catalysed coupling reaction of propargylic electrophiles with nucleophiles, ${ }^{16}$ typically affording only moderate levels of enantioselectivity. The induction of enantioselectivity at the allylic alkylation step of the mechanism has been studied using catechol, ${ }^{17}$ and $\beta$-ketoester nucleophiles; ${ }^{18}$ however, there are no examples in which a quaternary all-carbon centre had been installed enantioselectively. 


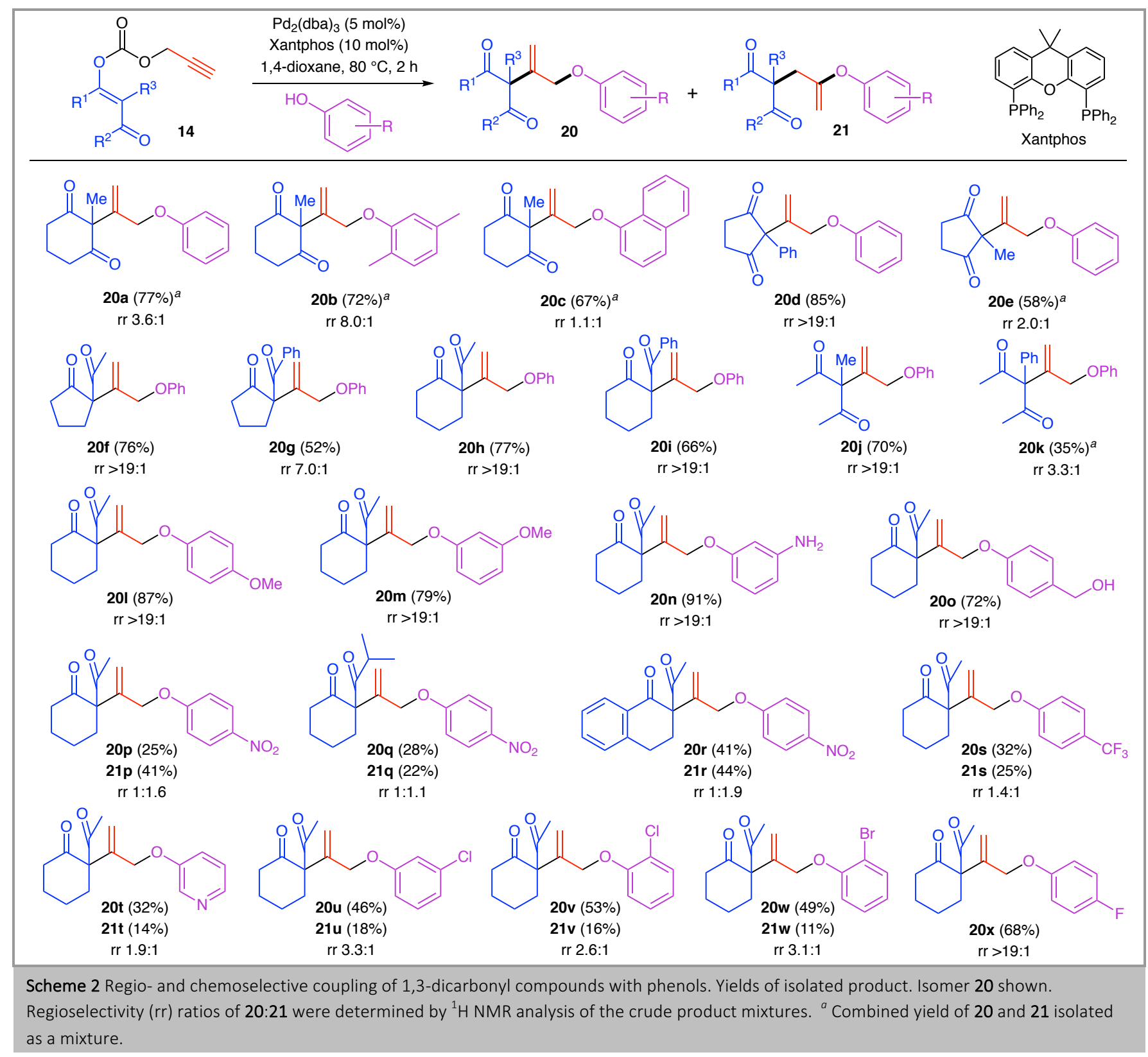

This article describes our investigations into the utility of this methodology and the challenges involved in controlling selectivity in the palladium-catalysed coupling of nucleophiles with propargylic electrophiles.

Phenol Nucleophiles. Our investigation began with the coupling of highly stabilised enolates, derived from cyclic 1,3diketones (1,3-cyclohexanedione, $\mathrm{p} K_{\mathrm{a}} 10$ in DMSO), ${ }^{19}$ with phenols as nucleophiles (phenol, $\mathrm{p} K_{\mathrm{a}} 18$ in DMSO), ${ }^{19}$ to afford desired product $\mathbf{2 0}$ and/or its regioisomer $\mathbf{2 1}$ (Scheme 2). In this one-pot process, an all-carbon quaternary centre is formed along with new $\mathrm{C}-\mathrm{C}$ and $\mathrm{C}-\mathrm{O}$ bonds. ${ }^{15}$ Upon optimisation, we found that Xantphos, a large-bite-angle ligand, was most suitable in this reaction and, in all cases, no homo-coupling of nucleophiles was observed. The use of monodentate or smaller bite-angle bidentate ligands leads to severe erosion of both reaction efficiency and selectivity. ${ }^{15}$ In the presence of phenols, 1,3-cyclohexanedione products $\mathbf{2 0 a}$ and $\mathbf{2 0 b}$ were formed with moderate to good regioselectivity; however, the reaction with 2-naphthol as the nucleophile was not selective (20c). The coupling of 5-membered 1,3-diketones with phenol to afford 20d and 20e also gave different levels of regioselectivity. It can be reasoned that the highly stabilised nature of cyclic 1,3diketone enolates can result in lower levels of regioselectivity either due to the lower nucleophilicity of the enolate, inhibiting the required intramolecular alkenylation process in $\mathbf{1 5}$ (vide supra, Scheme 1), or dissociation of the palladium complex from the highly stabilised enolate, paving the way to an uncontrolled order of addition of the two nucleophiles. In contrast, the use of propargyl carbonates, derived from less acidic acyclic 1,3-dicarbonyls ( $\mathrm{p} K_{\mathrm{a}} 13-16$ in DMSO), ${ }^{19}$ gave excellent regioselectivity in most cases (20f-k) in the coupling with phenol, presumably due to the tighter association of the enolate with the intermediate palladium complex following decarboxylation. Excellent regioselectivity was maintained with electron-rich phenols (201 and 20m), and no 
chemoselectivity issues were observed in the presence of other unprotected nucleophiles (20n and 20o), whereby allylic alkylation of the phenol functionality takes place exclusively owing to its higher acidity. In contrast, regioselectivity was low when electron-deficient phenols were utilised. For example, nitro-, trifluoromethyl- and pyridyl-substituted phenols afforded 20p-t with low regioselectivity. Similarly, halogenated phenols gave rise to $20 \mathbf{u}-\mathbf{w}$ with moderate selectivity, with the surprising exception of fluorinesubstituted 20x, which was isolated with complete regioselectivity. Given that electron-poor phenols are more acidic than their electron-rich counterparts (4-nitrophenol, $\mathrm{p} K_{\mathrm{a}}$ 11 DMSO), 20 and as acidic as, if not more than, acyclic 1,3dicarbonyl compounds, it is likely that the enolate formed in situ after decarboxylation undergoes protonation by the phenol nucleophile, which leads to the dissociation of the palladium complex and, thus, loss of regiocontrol.

1,3-Dicarbonyl Nucleophiles. Given the success in controlling the regioselectivity in the coupling of acyclic 1,3-diketones with relatively electron-rich phenols, we sought to explore whether the analogous coupling could be extended by replacing the phenol nucleophile with a 1,3-dicarbonyl compound (Scheme 3). ${ }^{21}$ Indeed, this reaction process was found to be very efficient using DPEphos as the large-bite-angle ligand, enabling the formation of two all-carbon quaternary carbon centres and two new $\mathrm{C}-\mathrm{C}$ bonds in a single step with complete regiocontrol and good chemoselectivity (23a-d) despite the structural similarities between the two nucleophiles. Given that high levels of regiocontrol are imparted by the tight association of the $\eta^{3}-\pi$ propargylpalladium(II) intermediate with the enolate after decarboxylation of $\mathbf{1 4}$, this reaction process becomes regioswitchable by utising an enol carbonate of 1,3-dicarbonyl nucleophile 22, thus paving the way to regioisomeric products 23e-h. Substitution of the 1,3-diketone nucleophile was tolerated to afford coupled products $\mathbf{2 3 i}-\mathbf{k}$, as well as regioisomers 23n and 23o; only a complex mixture of products was obtained in the formation of 23p. By analogy to electrondeficient phenols, the use of a significantly more acidic 1,3cyclohexanedione nucleophile in the formation of $\mathbf{2 3 1}$ afforded a mixture of products, with nucleophile homo-coupling being the major pathway. However, the selectivity in the formation of regioisomer $\mathbf{2 3 q}$ in the regioswitched process was higher. When an unsubstituted 1,3-diketone was utilised as a nucleophile, $\mathbf{2 3 m}$ was isolated in $56 \%$ yield, but the synthesis of its regioisomer $\mathbf{2 3 r}$ was not successful, presumably due to the presence of an acidic proton in the product structure. This process was extended to the use of 1,3-dicarbonyl compounds

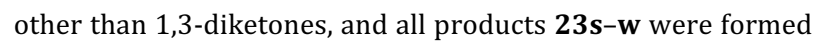
with complete regioselectivity. Since the 1,3-dicarbonyls tested are less acidic than 1,3-diketones, this process is analogous to the use of electron-rich phenols as nucleophiles, which had also afforded products with complete regioselectivity (vide supra, Scheme 2). Excellent selectivity was obtained in the formation of regioisomers $23 \mathbf{x}-\mathbf{a a}$, with the exception of 23ab, which resulted in a complex mixture of products.

$\boldsymbol{N}$-Nucleophiles. In addition to $O$ - and $C$-nucleophiles, we discovered that indole, an aromatic $N$-heterocycle, can also be readily deprotonated and alkylated as a coupling partner to afford 24a with complete regio- and chemoselectivity (Scheme
4).22 However, given that aromatic $N$-heterocycles are typically less acidic than phenols (indole, $\mathrm{p} K_{\mathrm{a}} 21$; pyrrole, $\mathrm{p} K_{\mathrm{a}} 23$, both in DMSO), ${ }^{19}$ a higher reaction temperature was required to facilitate deprotonation. Indeed, product $\mathbf{2 4 b}$ was obtained in relatively high yield, presumably due to the higher acidity of the indole nucleophile which bears an electron-withdrawing ester substituent. In contrast, electron-donating substitution on the indole unit negatively impacted on the efficiency of the reaction (24c). The use of carbazole as the nucleophile was successful (24d), and the reaction scope could also be extended to the use of propargyl enol carbonates derived from $\beta$-ketoesters (24e). The coupling process was broadened to the use of pyrrole as an analogue to indole (24f), albeit an electron-withdrawing substituent was essential to obtain a high yield of product $\mathbf{( 2 4} \mathbf{g}-\mathbf{j})$. Crucially, all reactions proceeded with complete regio- and chemoselectivity owing to both the tight association of the $\eta^{3}-\pi$-propargylpalladium(II) intermediate with the enolate following decarboxylation of $\mathbf{1 4}$ and the lack of protonation of the enolate by the $N$-heterocyclic nucleophile given the substantial difference in $\mathrm{p} K_{\mathrm{a}}$. This methodology was readily extended to other aromatic $N$ heterocycles, including azaindole, imidazole, benzimidazole and pyrazole, affording $\mathbf{2 4 k - n}$, respectively, with complete regiocontrol. Unfortunately, a much less acidic saturated cyclic amine as nucleophile failed to couple (24o).

Acidity Trends. The palladium-catalysed coupling of propargyl enol carbonates derived from 1,3-dicarbonyls relied upon the use of phenols (phenol, $\mathrm{p} K_{\mathrm{a}} 18$ in DMSO),19 1,3dicarbonyl compounds ( $\left.\mathrm{p} K_{\mathrm{a}} 13-16\right),{ }^{19}$ and aromatic $N$ heterocyclic nucleophiles ( $\mathrm{p} K_{\mathrm{a}} 19-23$, in DMSO) ${ }^{19}$ to obtain high levels of regiocontrol. As such, we set out to investigate the utility of nucleophiles outside of this $\mathrm{p} K_{\mathrm{a}}$ range. Based on the previous cases of low regioselectivity, where the external nucleophile was more acidic than the conjugate acid of the enolate, such as electron-deficient phenols (vide supra, Scheme 2), several other acidic species as nucleophiles were tested (Scheme 5). In this context, carboxylic acids as nucleophiles, which display similar acidity to electron-deficient phenols ( $\mathrm{p} K_{\mathrm{a}}$ 11-12 in DMSO), ${ }^{19}$ did afford products 25a-c, however, regioselectivity was again low and in line with the previous observation that undesired protonation of the enolate occurs prior to the alkenylation step. By increasing the acidity of the external nucleophile further, such as using $p$-toluenesulfonic acid, the reaction process was even more difficult to control (25d), leading to a complex mixture of products. On the other side of the $\mathrm{p} K_{\mathrm{a}}$ range, the reactivity of $C$-nucleophiles 27-30, all less acidic than phenols and 1,3-dicarbonyl compounds (e.g. cyclohexanone, $\mathrm{p} K_{\mathrm{a}} 26$ in DMSO), ${ }^{19}$ was tested. If the reaction were to proceed through the previously postulated mechanism (vide supra, Scheme 1), then deprotonation of a much less acidic nucleophile would be required. Unfortunately, the reaction with ketone $\mathbf{2 7}$ was unsuccessful and a complex mixture of products was obtained. To enhance the acidity of the carbonyl functionality and attempt to facilitate deprotonation, we explored cyclohexenone (28), which had been precedented to participate in an intramolecular coupling reaction, ${ }^{14 c}$ furanone $\mathbf{2 9}$, which would give an aromatic anion upon deprotonation that would be more stable than an enolate of a saturated lactone, and $\alpha$-difluorinated ester $\mathbf{3 0}$, which is more acidic than a simple ester due to the electron- 
withdrawing nature of the fluorine atoms. In all three cases, only a complex mixture of products was observed. It was, therefore, apparent that, overall, in the coupling of 1,3- dicarbonyl compounds with nucleophiles, high reaction efficiency and selectivity is most likely to be achieved with relatively acidic nucleophiles ( $\mathrm{p} K_{\mathrm{a}} \sim 13-23$ in DMSO).

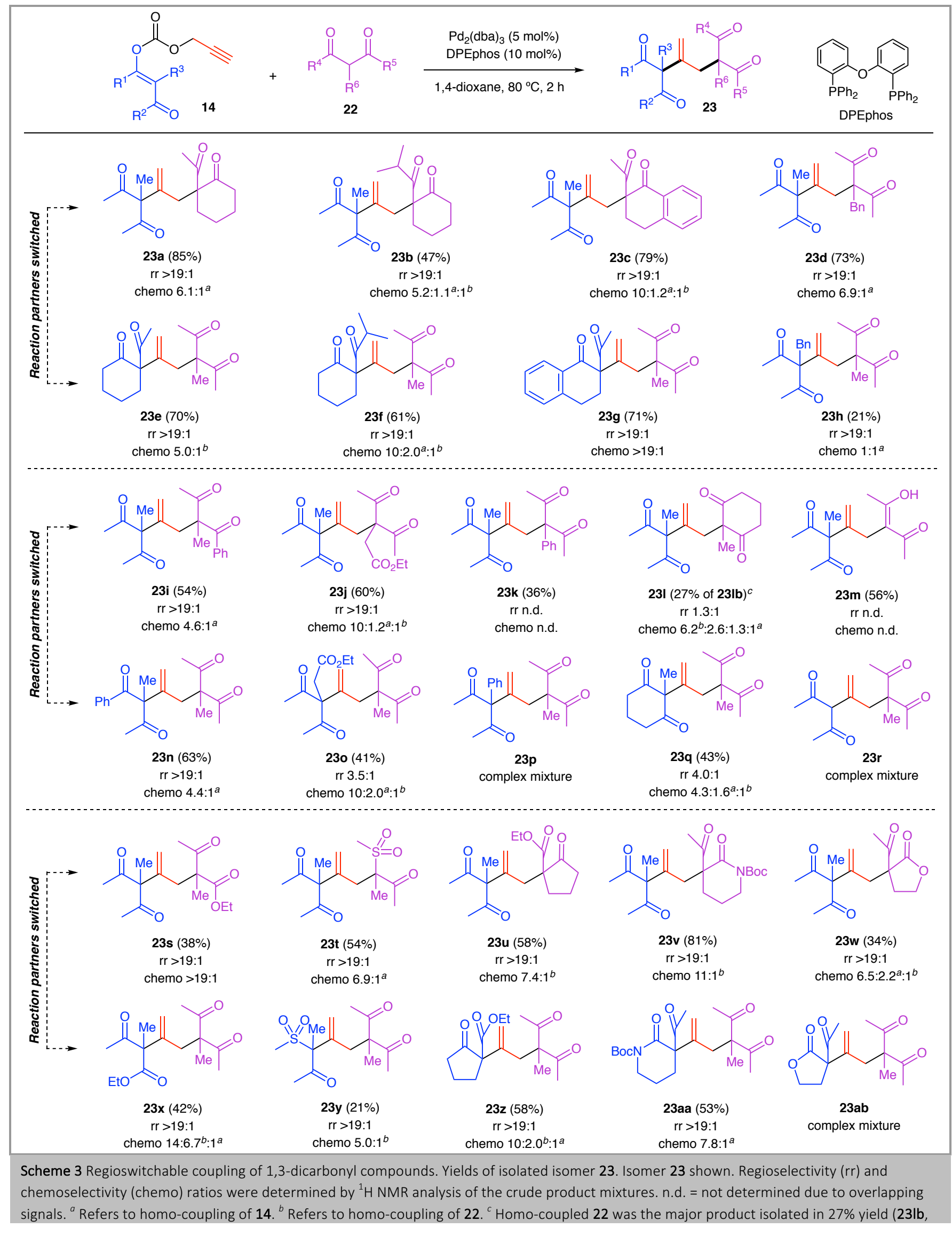




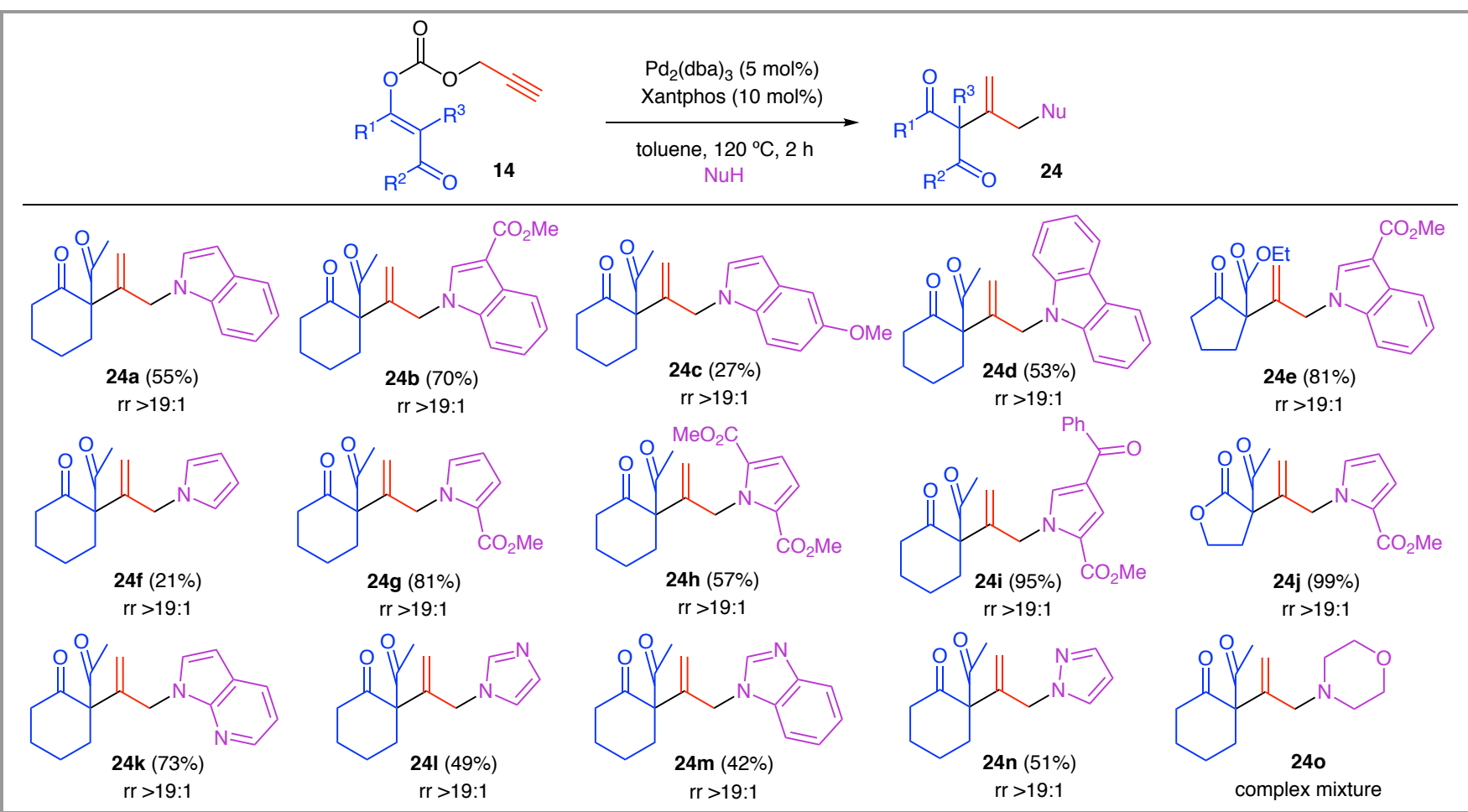

Scheme 4 Regio- and chemoselective coupling of 1,3-dicarbonyl compounds with $N$-nucleophiles. Yields of isolated isomer 24. Regioselectivity (rr) ratios were determined by ${ }^{1} \mathrm{H}$ NMR analysis of the crude product mixtures. n.d. = not determined due to overlapping signals. No homocoupling (chemoselectivity) of 14 or the $N$-nucleophile was observed in all cases.

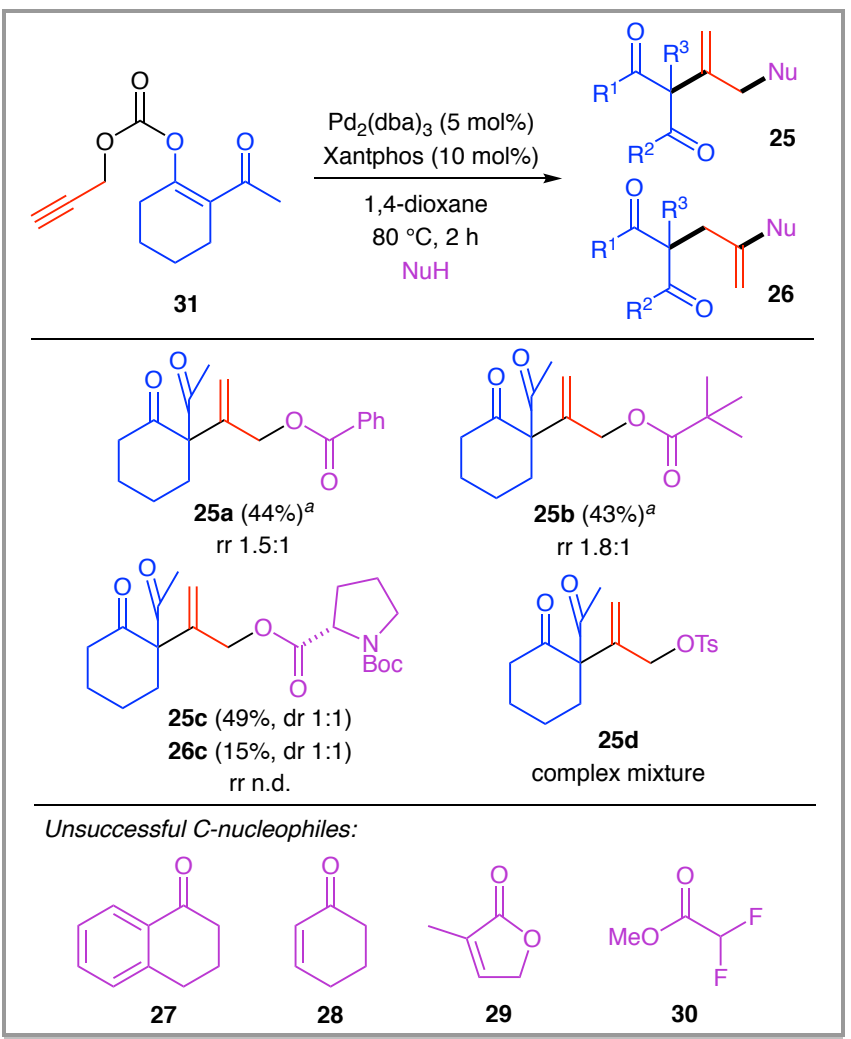

Scheme 5 Investigation of acidity trends. Isomer 25 shown. Regioselectivity ( $r$ ) and diastereoselectivity (dr) ratios were determined by ${ }^{1} \mathrm{H}$ NMR analysis of the crude product mixtures. n.d. = not determined due to overlapping signals. No homo-coupling (chemoselectivity) of 31 or the external nucleophile was observed in all cases. ${ }^{a}$ Combined yield of 25 and 26 isolated as a mixture.

Diastereoselective Synthesis. A crucial aspect of this project was the construction of quaternary all-carbon centres in a stereoselective manner. By utilising propargyl enol carbonate 31 and $\beta$-ketoester 32, two stereogenic quaternary centres were installed in a single step (Scheme 6). However, while the reaction conditions enabled the concerted control of regio- and chemoselectivity in the formation of $\mathbf{3 3}$, no induction of diastereoselectivity was observed, potentially due to the remoteness of the two chiral centres and the acyclic nature of 1,3-dicarbonyl compound 32. This observation gave an indication that the enantioselective installation of a stereogenic centre at the alkenylation step of the mechanism while relying on diastereocontrol to construct the second stereogenic centre at the allylic alkylation stage was likely to pose challenges. To avoid this difficulty, the next stage of the investigation focused on the enantioselective installation of a single stereogenic centre, either by means of alkenylation or allylic alkylation. Notwithstanding, such a process was still likely to be extremely demanding because to achieve both high levels of enantioselectivity and yield of the desired product, the simultaneous control of not only stereoselectivity, but also regio- and chemoselectivity is required. 


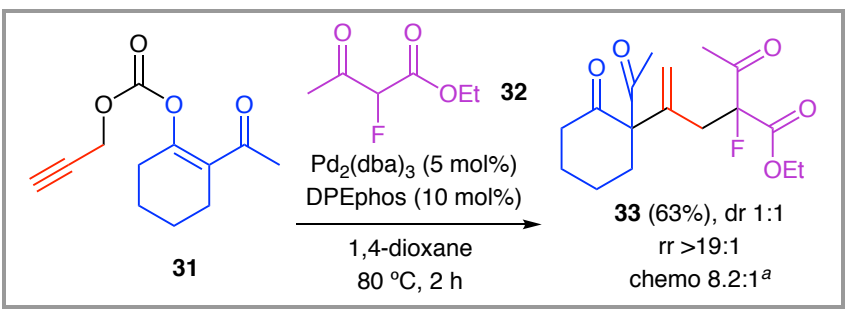

Scheme 6 Diastereoselective coupling. ${ }^{a}$ Refers to homo-coupling of 32.

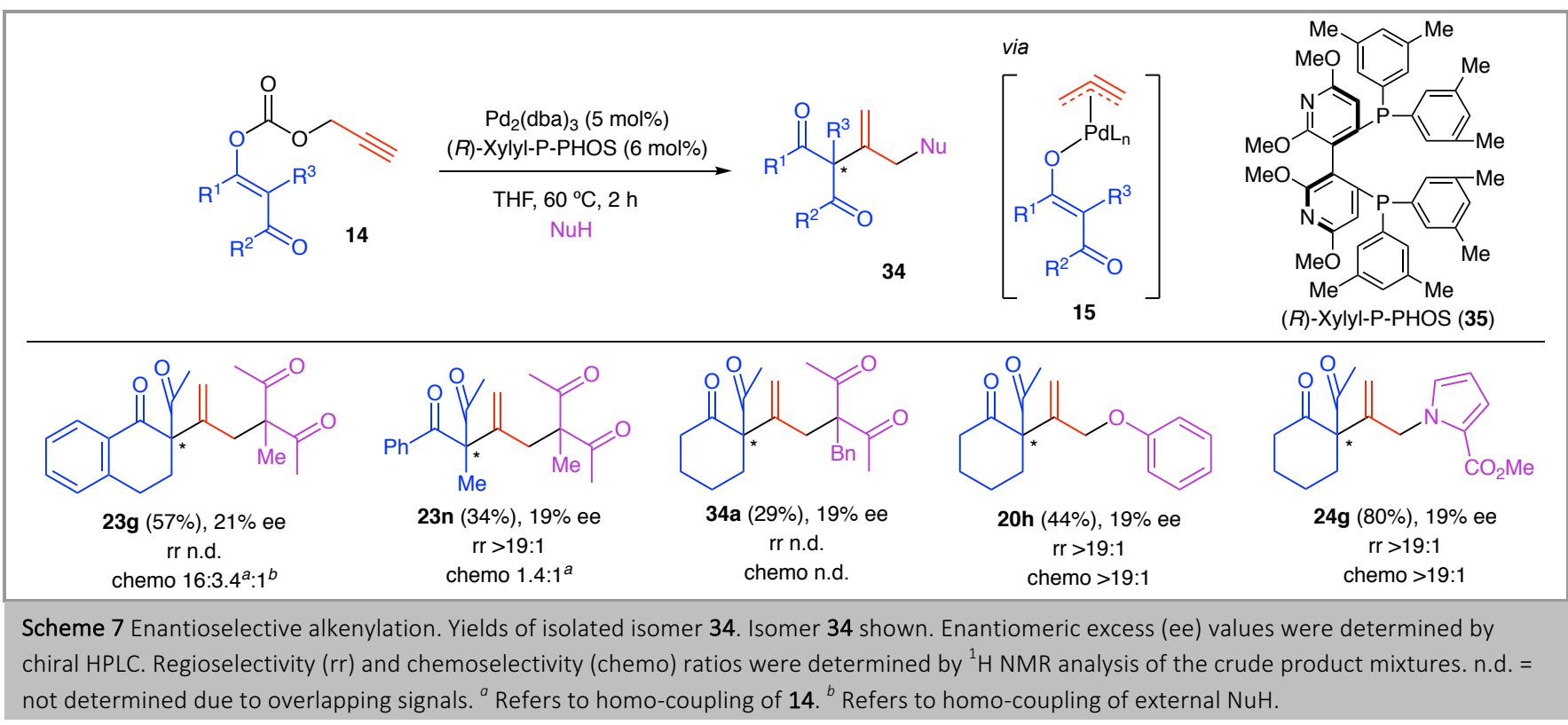

Enantioselective Alkenylation. The enantioselective construction of a stereogenic all-carbon quaternary centre in 34 by means of a chiral ligand sphere around the palladium centre necessitates stereocontrol at the alkenylation step of enolate 15 following decarboxylation (Scheme 7). In this context, 30 chiral bisphosphines were screened, including the BINAP, SEGPHOS, BIPHEP, P-PHOS, PhanePhos, Trost, PHOX and phosphoramidite ligand families, and reaction parameters, including solvent, time and temperature, carefully optimised (see Supporting Information for ligand structures and full optimisation details). (R)-Xylyl-P-PHOS (35) was identified as the optimal ligand in terms of yield and selectivity. Although 23g was formed in 57\% yield, enantioselectivity was low $(21 \%$ ee). Similar levels of enantioselectivity were observed in the formation of $\mathbf{2 3 n}$ and $\mathbf{3 4 a}$, but product yields were low due to inadequate levels of control of either regio- or chemoselectivity. In addition to the use of 1,3-dicarbonyls, phenol and pyrrole nucleophiles were utilised, both of which afforded $20 \mathrm{~h}$ and $\mathbf{2 4 g}$ in $19 \%$ ee whilst maintaining full regioand chemoselectivity.

Enantioselective Allylic Alkylation. The enantioselective construction of a quaternary all-carbon centre via the allylic alkylation of intermediate $\mathbf{3 8}$ was developed in a fashion analogous to the enantioselective alkenylation process (Scheme 8), where again the simultaneous control of regio-, chemo- and stereoselectivity was essential. Following a screen of chiral ligands for palladium (see Supporting Information for ligand structures and full optimisation details), $(R)$-Tol-BINAP (37) was found to give the best balance of reaction efficiency and enantioselectivity. Using this ligand and 1,3-diketone 22 with a defined enolate geometry upon deprotonation, product 23c was formed in a good yield owing to complete regiocontrol and good chemoselectivity; however, enantioselectivity was low $(27 \%$ ee). 
<smiles>C#CCOC(=O)OC(C)=C(C)C(C)=O</smiles><smiles>[R7]C(=O)C([10BH2])C(=O)[18OH]</smiles>

22

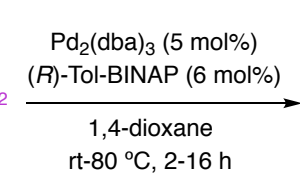

$\mathrm{rt}-80^{\circ} \mathrm{C}, 2-16 \mathrm{~h}$

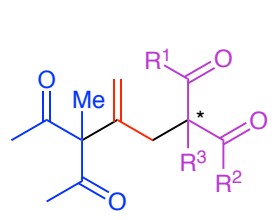

36

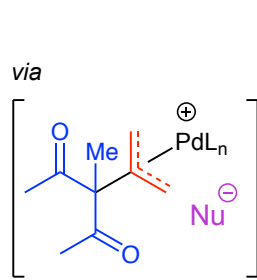

38

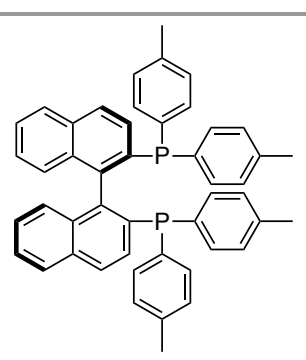

(R)-Tol-BINAP (37)
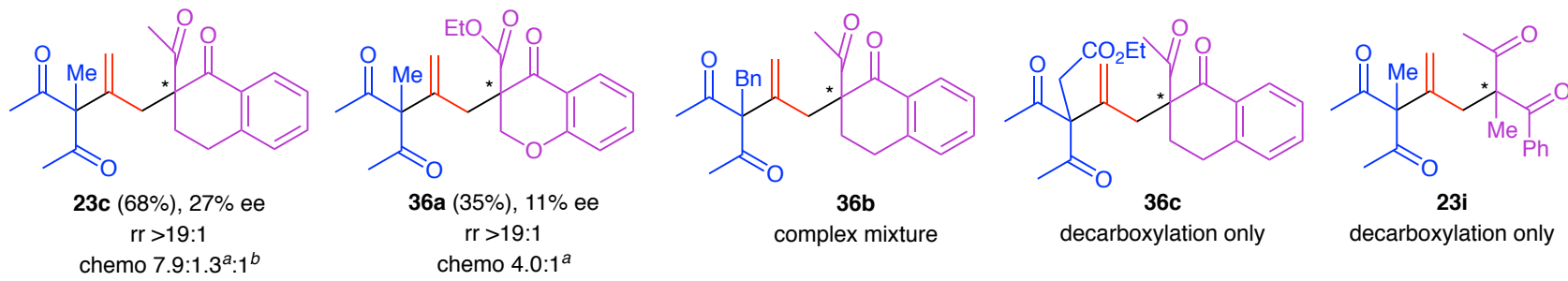

decarboxylation only

Scheme 8 Enantioselective allylic alkylation. Yields of isolated isomer 36. Isomer 36 shown. Enantiomeric excess (ee) values were determined by chiral HPLC. Regioselectivity ( $r$ ) and chemoselectivity (chemo) ratios were determined by ${ }^{1} \mathrm{H}$ NMR analysis of the crude product mixtures. ${ }^{a}$ Refers to homo-coupling of $14{ }^{b}$ Refers to homo-coupling of 22.

When a $\beta$-ketoester was employed as a nucleophile, 36a was formed with complete regiocontrol, but the yield was low due to modest chemoselectivity; enantioselectivity was poor. All attempts to extend this process to a broader range of substrates by exploring substitution led to disappointing results: the attempted formation of $\mathbf{3 6} \mathbf{b}$ afforded a complex mixture of products, indicating low levels of selectivity, whereas 36c and 23i were not formed due to the corresponding propargyl enol carbonates only undergoing decarboxylation and failing to take part in the desired reaction process. Based on these results, it is apparent that the contemporaneous control of regio-, chemoand stereoselectivity in the palladium-catalysed intermolecular coupling of nucleophiles in the presence of propargylic electrophiles remains to be notoriously difficult.

In conclusion, this research programme has enabled us to identify and explore the utility of propargyl enol carbonates, derived from 1,3-dicarbonyls, in the palladium-catalysed crosscoupling with nucleophiles for the construction of quaternary all-carbon centres. We have successfully developed chemical processes for the decarboxylative coupling of enolates with a range of nucleophiles with high levels of regio- and chemoselectivity owing to the tight association of the $\eta^{3}-\pi$ propargylpalladium(II) intermediate with the enolate following decarboxylation. A careful analysis of acidity trends of nucleophiles has indicated that relatively acidic nucleophiles ( $\mathrm{p} K_{\mathrm{a}} \sim 13-23$ in DMSO), such as phenols, 1,3-dicarbonyl compounds and aromatic $N$-heterocycles, give rise to excellent levels of regiocontrol. The use of more acidic nucleophiles, such as electron-deficient phenols, cyclic 1,3-diketones and carboxylic acids, results in low regioselectivity, presumably owing to the premature protonation of the intermediate enolate and, thus, dissociation of the palladium metal centre from the resulting neutral enol. Similarly, less acidic carbon-based nucleophiles, such as unstabilised enolates derived from ketones and esters, failed to take part in the desired coupling process. Crucially, this approach has enabled us to explore the opportunities for the catalytic enantioselective construction of quaternary all-carbon stereogenic centres. Both enantioselective alkenylation and allylic alkylation processes were explored; however, despite extensive screens of chiral ligands, the need for simultaneous control of regio-, chemo- and stereoselectivity was a formidable challenge to overcome. While it was possible to retain high levels of regiocontrol and chemoselectivity in many cases, the levels of enantioselectivity were generally low. The stereoselective installation of quaternary carbon centres by means of palladium-catalysed coupling of nucleophiles with propargylic electrophiles remains to be a major challenge for synthetic chemists, yet offers ample opportunities for its broader development and application.

\section{The experimental section has no title; please leave this line here.}

All commercially available starting materials were used as received without further purification. Solvents were of reagent grade and dried prior to use. Petrol refers to the fraction of petroleum ether that boils between 40 and $60{ }^{\circ} \mathrm{C}$. All reactions were performed under an argon atmosphere in oven dry glassware. Reactions were monitored by thin layer chromatography using pre-coated silica gel plates with a fluorescent indicator (254 $\mathrm{nm}$ ) and visualized by UV light $(254 \mathrm{~nm})$ and by staining with potassium permanganate or aqueous acidic ammonium molybdate(IV) solutions. Flash column chromatography was carried out using Fisher silica gel (60 ̊ particle size, 230-400 mesh). NMR spectra were recorded on either 400 or $300 \mathrm{MHz}$ instruments $\left({ }^{1} \mathrm{H} \mathrm{NMR}\right.$ at 400 and $300 \mathrm{MHz}$, respectively, and ${ }^{13} \mathrm{C}\left\{{ }^{1} \mathrm{H}\right\} \mathrm{NMR}$ at 100 and $75 \mathrm{MHz}$, respectively) in $\mathrm{CDCl}_{3}$. Residual solvent $\mathrm{CHCl}_{3}$ was referenced at 7.26 ppm for ${ }^{1} \mathrm{H}$ NMR spectra, and the central resonance of $\mathrm{CDCl}_{3}$ was referenced to $77.0 \mathrm{ppm}$ for ${ }^{13} \mathrm{C}\left\{{ }^{1} \mathrm{H}\right\}$ NMR spectra. IR spectra were recorded on an FTIR spectrometer as a neat film. High resolution mass spectrometry data were recorded using electron spray ionisation on an LCMS-IT-TOF mass spectrometer. Melting points were uncorrected.

The following compounds have been previously reported in reactions using phenols: ${ }^{15}$ 20a, 20d, 20f, 20h-j, 20l-p and 20x; 1,3-dicarbonyl compounds: ${ }^{21}$ 23a, 23c-g, 23i, 23j, 23n, 23t-v, 23z, 23aa, 33 and 36a; $N$-heterocycles: ${ }^{22}$ 24a-n. With the exception of 39, 41 and 43-45, syntheses of all propargyl enol carbonates 14 and $\mathbf{3 1}$ have been reported and appropriate references are provided in each case below.

\section{Procedures}

Method A. Carbonate 14 (0.24 mmol), $\mathrm{Pd}_{2}(\mathrm{dba})_{3}(11 \mathrm{mg}, 0.012 \mathrm{mmol})$, Xantphos (13.9 mg, $0.024 \mathrm{mmol}$ ) and the phenol nucleophile $(0.26$ mmol) were added to a dried tube under argon. The tube was fitted with a septum and purged further with argon. 1,4-Dioxane $(1.5 \mathrm{~mL})$ was 
added and the sealed tube was added to an oil bath preheated to $80{ }^{\circ} \mathrm{C}$. The mixture was stirred at $80{ }^{\circ} \mathrm{C}$ for 2 hours, then cooled to room temperature, concentrated in vacuo and purified by flash column chromatography. Ratio 20:21 was determined by ${ }^{1} \mathrm{H}$ NMR spectroscopy of the crude product mixture prior to purification.

Method B. Carbonate 14 (0.24 mmol), $\mathrm{Pd}_{2}(\mathrm{dba})_{3}(11 \mathrm{mg}, 0.012 \mathrm{mmol})$, DPEphos (13.1 mg, $0.024 \mathrm{mmol}$ ) and the 1,3-dicarbonyl nucleophile $(0.24 \mathrm{mmol})$ were added to a dried tube under argon. The tube was fitted with a septum and purged further with argon. 1,4-Dioxane $(1.5 \mathrm{~mL})$ was added and the sealed tube was added to an oil bath preheated to $80^{\circ} \mathrm{C}$. The mixture was stirred at $80{ }^{\circ} \mathrm{C}$ for 2 hours, then cooled to room temperature, concentrated in vacuo and purified by flash column chromatography. Regioselectivity and chemoselectivity ratios were determined by ${ }^{1} \mathrm{H}$ NMR spectroscopy of the crude product mixture prior to purification.

Method C. Carbonate 14 (0.24 mmol), $\mathrm{Pd}_{2}(\mathrm{dba})_{3}(11 \mathrm{mg}, 0.012 \mathrm{mmol})$, Xantphos (13.9 mg, $0.024 \mathrm{mmol}$ ) and the $N$-heterocyclic nucleophile ( $0.24 \mathrm{mmol})$ were added to a dried tube under argon. The tube was fitted with a septum and purged further with argon. Toluene $(1.5 \mathrm{~mL})$ was added and the sealed tube was added to an oil bath preheated to $120{ }^{\circ} \mathrm{C}$. The mixture was stirred at $120^{\circ} \mathrm{C}$ for 2 hours, then cooled to room temperature, concentrated in vacuo and purified by flash column chromatography.

Method D. Carbonate 14 (0.24 mmol), $\mathrm{Pd}_{2}(\mathrm{dba})_{3}(11 \mathrm{mg}, 0.012 \mathrm{mmol}$ ), Xantphos (13.9 mg, $0.024 \mathrm{mmol}$ ) and the carboxylic acid nucleophile $(0.24 \mathrm{mmol})$ were added to a dried tube under argon. The tube was fitted with a septum and purged further with argon. 1,4-Dioxane $(1.5 \mathrm{~mL})$ was added and the sealed tube was added to an oil bath preheated to $80{ }^{\circ} \mathrm{C}$. The mixture was stirred at $80{ }^{\circ} \mathrm{C}$ for 2 hours, then cooled to room temperature, concentrated in vacuo and purified by flash column chromatography. Ratio 25:26 was determined by ${ }^{1} \mathrm{H}$ NMR spectroscopy of the crude product mixture prior to purification.

\section{2-(3-(2,5-Dimethylphenoxy)prop-1-en-2-yl)-2-methylcyclohexane-} 1,3-dione (20b):

Following method A, carbonate $\mathbf{1 4}^{15}$ (50 $\mathrm{mg}, 0.24 \mathrm{mmol}$ ) was reacted with 2,5-dimethylphenol (32 $\mathrm{mg}, 0.26 \mathrm{mmol})$. Flash column chromatography [Petrol:EtOAc 19:1] afforded an inseparable mixture of 20b and $\mathbf{2 1 b}$ in a $13: 1$ ratio (48 $\mathrm{mg}, 72 \%$ ) as an orange oil. $R_{F} 0.36$ [Petrol:EtOAc 3:1].

IR (film): 2878, 1703, $1673 \mathrm{~cm}^{-1}$.

${ }^{1} \mathrm{H}$ NMR (400 MHz, $\mathrm{CDCl}_{3}$, resonances due to 20b quoted): $\delta=7.00(\mathrm{~d}, J=$ $7.4 \mathrm{~Hz}, 1 \mathrm{H}$ ), 6.70 (d, $J=7.5 \mathrm{~Hz}, 1 \mathrm{H}), 6.59$ (s, $1 \mathrm{H}), 5.52(\mathrm{t}, J=1.3 \mathrm{~Hz}, 1 \mathrm{H}$ ), $5.13(\mathrm{~s}, 1 \mathrm{H}), 4.39$ (s, 2H), 2.86 (ddd, $J=16.5,8.5,5.4 \mathrm{~Hz}, 2 \mathrm{H}), 2.60$ (ddd, $J$ $=16.6,8.0,5.0 \mathrm{~Hz}, 2 \mathrm{H}), 2.30(\mathrm{~s}, 3 \mathrm{H}), 2.19-2.09(\mathrm{~m}, 1 \mathrm{H}), 2.16(\mathrm{~s}, 3 \mathrm{H}), 1.90-$ $1.77(\mathrm{~m}, 1 \mathrm{H}), 1.45(\mathrm{~s}, 3 \mathrm{H})$

${ }^{13} \mathrm{C}$ NMR (100 $\mathrm{MHz}, \mathrm{CDCl}_{3}$, resonances due to $20 \mathbf{b}$ quoted): $\delta=207.9$, $156.2,143.8,136.8,130.7,123.9,122.0,116.6,113.0,70.0,68.7,38.7$, $21.4,19.5,17.7,16.0$

HRMS (ESI): $m / z[\mathrm{M}+\mathrm{Na}]^{+}$calcd for $\mathrm{C}_{18} \mathrm{H}_{22} \mathrm{O}_{3}$ : 309.1461; found: 309.1448 .

\section{2-Methyl-2-(3-(naphthalen-1-yloxy)prop-1-en-2-yl)cyclohexane-}

1,3-dione $(20 \mathrm{c})$ and 2-methyl-2-(2-(naphthalen-1-
yloxy)allyl)cyclohexane-1,3-dione (21c):

Following method A, carbonate $\mathbf{1 4}^{15}$ (50 mg, $0.24 \mathrm{mmol}$ ) was reacted with 2-naphthol ( $37 \mathrm{mg}, 0.26 \mathrm{mmol}$ ). Flash column chromatography [Petrol:EtOAc 19:1] afforded an inseparable mixture of 20c and 21c in a 1.6:1 ratio $(50 \mathrm{mg}, 67 \%)$ as an orange oil. $R_{F} 0.25$ [Petrol:EtOAc 3:1].

IR (film): 3348, 1669, $1554 \mathrm{~cm}^{-1}$.

${ }^{1} \mathrm{H}$ NMR (400 MHz, $\mathrm{CDCl}_{3}$, isomer 21c annotated by an asterisk): $\delta=$ 8.26-6.75 (m, 7H and 7H*), $5.63\left(\mathrm{t}, J=1.3 \mathrm{~Hz}, 1 \mathrm{H}^{*}\right), 5.26\left(\mathrm{~s}, 1 \mathrm{H}^{*}\right), 4.62(\mathrm{~s}$, $2 \mathrm{H}^{*}$ ), 4.12 (dd, $\left.J=2.3,1.0 \mathrm{~Hz}, 1 \mathrm{H}\right), 3.74(\mathrm{~d}, J=2.5 \mathrm{~Hz}, 1 \mathrm{H}), 3.16(\mathrm{~s}, 2 \mathrm{H}$ ), 2.86-2.65 (m, $4 \mathrm{H}$ and $\left.2 \mathrm{H}^{*}\right), 2.65-2.56\left(\mathrm{~m}, 2 \mathrm{H}^{*}\right), 2.13-2.00\left(\mathrm{~m}, 1 \mathrm{H}^{*}\right), 1.99$ $1.86(\mathrm{~m}, 2 \mathrm{H}), 1.87-1.77\left(\mathrm{~m}, 1 \mathrm{H}^{*}\right), 1.51\left(\mathrm{~s}, 3 \mathrm{H}^{*}\right), 1.39(\mathrm{~s}, 3 \mathrm{H})$.
${ }^{13} \mathrm{C}$ NMR (100 MHz, $\mathrm{CDCl}_{3}$, mixture of 20c and 21c): $\delta=210.4,208.4$, 158.6, 151.9, 150.3, 143.3, 135.0, 134.9, 127.9, 127.7, 126.6 (2C), 126.4, $126.4,126.0,125.9,125.2,125.0,122.1,121.9,120.4,117.5,117.2,108.6$, $105.8,89.4,69.4,69.2,62.4,40.1,38.7,38.0,22.2,20.1,17.8,17.5$.

HRMS (ESI): $m / z$ [M+H] ${ }^{+}$calcd for $\mathrm{C}_{20} \mathrm{H}_{20} \mathrm{O}_{3}: 309.1485$; found: 309.1474 .<smiles>C#CCOC(=O)OC1=C(C)C(=O)CC1</smiles>

\section{3-0xo-2-methylcyclopent-1-enyl prop-2-ynyl carbonate (39):}

A suspension of sodium hydride ( $60 \mathrm{wt} \%, 220 \mathrm{mg}, 5.5 \mathrm{mmol})$ in mineral oil was washed with petrol ( $2 \mathrm{~mL})$. Tetrahydrofuran $(25 \mathrm{~mL})$ was added and the mixture was cooled to $0{ }^{\circ} \mathrm{C}$. 2-Methyl-1,3-cyclopentadione (560 $\mathrm{mg}, 5.0 \mathrm{mmol}$ ) was added as a solid. After stirring at $0{ }^{\circ} \mathrm{C}$ for 10 minutes, propargyl chloroformate ( $539 \mu \mathrm{L}, 5.5 \mathrm{mmol}$ ) was added dropwise. The mixture was allowed to warm to room temperature and stirred at this temperature for 1.5 hours. The reaction was quenched by addition of aq. $\mathrm{HCl}(10 \%, 50 \mathrm{~mL})$ and the mixture was extracted with EtOAc $(3 \times 50$ $\mathrm{mL})$. The combined organic phases were washed with aq. $\mathrm{NaHCO}_{3}(3 \mathrm{x}$ $50 \mathrm{~mL})$, brine $(100 \mathrm{~mL})$, dried $\left(\mathrm{MgSO}_{4}\right)$ and concentrated in vacuo. Flash column chromatography [Petrol:EtOAc 4:1] afforded carbonate 39 (590 $\mathrm{mg}, 61 \%$ ) as a pale yellow oil. $R_{F} 0.17$ [Petrol:EtOAc 4:1].

IR (film): 3353, 2883, 2097, 1750, $1642 \mathrm{~cm}^{-1}$.

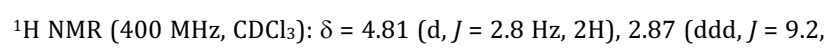
$4.0,2.0 \mathrm{~Hz}, 2 \mathrm{H}), 2.61(\mathrm{t}, J=2.4 \mathrm{~Hz}, 1 \mathrm{H}), 2.53-2.48(\mathrm{~m}, 2 \mathrm{H}), 1.63(\mathrm{t}, J=2.0$ $\mathrm{Hz}, 3 \mathrm{H})$.

${ }^{13} \mathrm{C}$ NMR $\left(100 \mathrm{MHz}, \mathrm{CDCl}_{3}\right): \delta=205.5,174.7,149.9,125.8,76.7,75.8$, $56.3,34.2,26.4,6.3$.

HRMS (ESI): $m / z$ [M+H] ${ }^{+}$calcd for $\mathrm{C}_{10} \mathrm{H}_{10} \mathrm{O}_{4}:$ 195.0652; found: 195.0654 .

2-Methyl-2-(3-phenoxyprop-1-en-2-yl)cyclopentane-1,3-dione (20e) and 2-methyl-2-(2-phenoxyallyl)cyclopentane-1,3-dione (21e):

Following method A, carbonate 39 ( $47 \mathrm{mg}, 0.24 \mathrm{mmol}$ ) was reacted with phenol ( $25 \mathrm{mg}, 0.26 \mathrm{mmol}$ ). Flash column chromatography [Petrol:EtOAc 9:1] afforded an inseparable mixture of $20 \mathbf{e}$ and $21 \mathbf{e}$ in a 2.0:1 ratio (34 mg, 58\%) as a clear oil. $R_{F} 0.25$ [Petrol:EtOAc 4:1].

IR (film): 3017, 2883, 2828, 1739, 1698, 1623, $1572 \mathrm{~cm}^{-1}$.

${ }^{1} \mathrm{H}$ NMR (400 MHz, $\mathrm{CDCl}_{3}$, isomer 21e annotated by an asterisk): $\delta=7.30$ $(\mathrm{t}, J=7.6 \mathrm{~Hz}, 1 \mathrm{H}), 7.25-7.21(\mathrm{~m}, 2 \mathrm{H}), 7.12\left(\mathrm{tt}, J=7.2,1.2 \mathrm{~Hz}, 1 \mathrm{H}^{*}\right), 6.95(\mathrm{tt}$, $\left.J=7.2,1.2 \mathrm{~Hz}, 2 \mathrm{H}^{*}\right), 6.90-6.86\left(\mathrm{~m}, 2 \mathrm{H}^{*}\right), 6.78-6.73(\mathrm{~m}, 2 \mathrm{H}), 5.48(\mathrm{t}, J=1.6$ $\mathrm{Hz}, 1 \mathrm{H}), 5.32(\mathrm{t}, J=0.8 \mathrm{~Hz}, 1 \mathrm{H}), 4.46(\mathrm{t}, J=1.2 \mathrm{~Hz}, 2 \mathrm{H}), 4.15-4.12\left(\mathrm{~m}, 1 \mathrm{H}^{*}\right)$, $3.82\left(\mathrm{~d}, J=2.4 \mathrm{~Hz}, 1 \mathrm{H}^{*}\right), 2.85(\mathrm{~s}, 4 \mathrm{H}), 2.82\left(\mathrm{~s}, 2 \mathrm{H}^{*}\right), 2.75(\mathrm{dt}, J=10.0,2.4$ $\left.\mathrm{Hz}, 4 \mathrm{H}^{*}\right), 1.32$ (s, 3H), 1.15 (s, 3H*).

${ }^{13} \mathrm{C}$ NMR (100 $\mathrm{MHz}, \mathrm{CDCl}_{3}$, isomer 21e annotated by an asterisk): $\delta=$ $215.8^{*}, 213.3,157.7^{*}, 157.3,153.9^{*}, 141.5,129.7,129.6,124.8^{*}, 121.7^{*}$, $120.8^{*}, 116.6,114.2,89.5^{*}, 68.9,59.5,53.9^{*}, 39.6^{*}, 34.8^{*}, 34.7,20.7^{*}$, 18.7 .

HRMS (ESI): $m / z[\mathrm{M}+\mathrm{Na}]^{+}$calcd for $\mathrm{C}_{15} \mathrm{H}_{16} \mathrm{O}_{3}: 267.0992$; found: 267.0989.

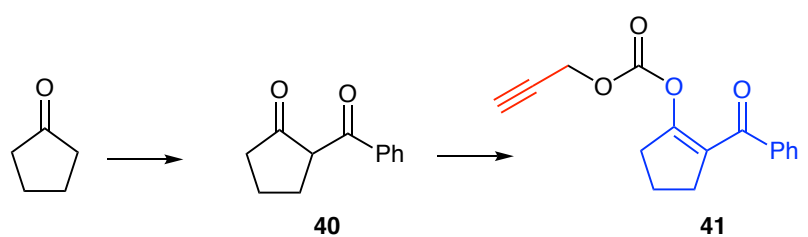

2-Benzoylcyclopentanone $(40)^{23}$

To a stirred solution of cyclopentanone (4.42 mL, $50 \mathrm{mmol}$ ) and $p$ toluenesulfonic acid (476 mg, $2.5 \mathrm{mmol})$ in toluene $(100 \mathrm{~mL})$ was added pyrrolidine $(6.15 \mathrm{~mL}, 75 \mathrm{mmol})$. The mixture was heated to reflux at 110 ${ }^{\circ} \mathrm{C}$ under Dean-Stark conditions for 16 hours, then allowed to cool to 
room temperature. The mixture was concentrated in vacuo to afford the crude enamine $(6.31 \mathrm{~g})$ as a dark orange oil.

To a stirred solution of the crude enamine $(4.17 \mathrm{~g}, 30 \mathrm{mmol})$ in toluene $(80 \mathrm{~mL})$ was added triethylamine $(5.82 \mathrm{~mL}, 42 \mathrm{mmol}$ ) and benzoyl chloride $(4.88 \mathrm{~mL}, 42 \mathrm{mmol})$. The mixture was heated to reflux at $110^{\circ} \mathrm{C}$ for 1.5 hours, then allowed to cool to room temperature. Aq. $\mathrm{HCl}(10 \%$, $30 \mathrm{~mL}$ ) was added and the mixture was heated to reflux at $110{ }^{\circ} \mathrm{C}$ for 30 minutes, then allowed to cool to room temperature. Another portion of aq. $\mathrm{HCl}(10 \%, 20 \mathrm{~mL})$ was added and the mixture was extracted with EtOAc $(3 \times 50 \mathrm{~mL})$. The combined organic phases were washed with brine $(100 \mathrm{~mL})$, dried $\left(\mathrm{MgSO}_{4}\right)$ and concentrated in vacuo. Flash column chromatography [Petrol:EtOAc 49:1-9:1] afforded a mixture of three compounds as a yellow solid. The major component was the enol tautomer of diketone 40. $R_{F} 0.66$ [Petrol:EtOAc 3:1].

IR (film): 2985, 2938, 1717, $1624 \mathrm{~cm}^{-1}$.

${ }^{1} \mathrm{H}$ NMR (400 MHz, $\left.\mathrm{CDCl}_{3}\right): \delta=8.12(\mathrm{dd}, J=8.3,1.4 \mathrm{~Hz}, 2 \mathrm{H}), 7.79-7.75(\mathrm{~m}$, $1 \mathrm{H}), 7.48-7.44(\mathrm{~m}, 2 \mathrm{H}), 2.87(\mathrm{t}, J=7.1 \mathrm{~Hz}, 2 \mathrm{H}), 2.50(\mathrm{t}, J=7.9 \mathrm{~Hz}, 2 \mathrm{H})$, 2.01-1.92 (m, 2H), (signal due to $\mathrm{OH}$ not observed).

${ }^{13} \mathrm{C}$ NMR $\left(100 \mathrm{MHz}, \mathrm{CDCl}_{3}\right): \delta=210.6,171.8,133.8,130.7,128.6,128.4$, $109.4,37.7,28.4,21.4$.

HRMS (ESI): $m / z$ [M+Na] ${ }^{+}$calcd for $\mathrm{C}_{12} \mathrm{H}_{12} \mathrm{O}_{2}: 211.0730$; found: 211.0730 .

\section{(2-0xocyclopentylidene)(phenyl)methyl prop-2-ynyl carbonate} (41)

A suspension of sodium hydride (60 wt\%, $117 \mathrm{mg}, 2.93 \mathrm{mmol}$ ) in mineral oil was washed with petrol $(2 \mathrm{~mL})$. Tetrahydrofuran $(20 \mathrm{~mL})$ was added and the mixture was cooled to $0{ }^{\circ} \mathrm{C}$. A solution of 2 benzoylcyclopentanone $(\mathbf{4 0}, 500 \mathrm{mg}, 2.66 \mathrm{mmol})$ in tetrahydrofuran (2 $\mathrm{mL}$ ) was added dropwise. After stirring at $0{ }^{\circ} \mathrm{C}$ for 10 minutes, propargyl chloroformate $(286 \mu \mathrm{L}, 2.93 \mathrm{mmol})$ was added dropwise. The mixture was allowed to warm to room temperature and stirred at this temperature for 1 hour. The reaction was quenched by addition of aq. $\mathrm{HCl}(10 \%, 20 \mathrm{~mL})$ and the mixture was extracted with EtOAc $(3 \times 20$ $\mathrm{mL})$. The combined organic phases were washed with brine $(50 \mathrm{~mL})$, dried $\left(\mathrm{MgSO}_{4}\right)$ and concentrated in vacuo. Flash column chromatography [Petrol:EtOAc 19:1-4:1] afforded carbonate 41 (320 mg, 10\% from cyclopentanone) as a brown oil. $R_{F} 0.34$ [Petrol:EtOAc 4:1].

IR (film): 3287, 2967, 2130, 1766, 1715, $1619 \mathrm{~cm}^{-1}$.

${ }^{1} \mathrm{H}$ NMR (400 MHz, $\mathrm{CDCl}_{3}$ ): $\delta=7.60-7.56(\mathrm{~m}, 2 \mathrm{H}), 7.44-7.41(\mathrm{~m}, 3 \mathrm{H}), 4.83$ $(\mathrm{d}, J=2.5 \mathrm{~Hz}, 2 \mathrm{H}), 2.94(\mathrm{t}, J=7.1 \mathrm{~Hz}, 2 \mathrm{H}), 2.57(\mathrm{t}, J=2.5 \mathrm{~Hz}, 1 \mathrm{H}), 2.40(\mathrm{t}, J$ $=7.8 \mathrm{~Hz}, 2 \mathrm{H}$ ), 1.95 (quint, $J=7.4 \mathrm{~Hz}, 2 \mathrm{H}$ ).

${ }^{13} \mathrm{C}$ NMR $\left(100 \mathrm{MHz}, \mathrm{CDCl}_{3}\right): \delta=204.9,151.7,147.6,133.5,130.4,128.4$, $128.1,124.7,76.6,76.0,56.0,39.2,30.3,20.5$.

\section{2-Benzoyl-2-(3-phenoxyprop-1-en-2-yl)cyclopentanone (20g):}

Following method A, carbonate $\mathbf{4 1}(64.8 \mathrm{mg}, 0.24 \mathrm{mmol})$ was reacted with phenol (25 mg, $0.26 \mathrm{mmol}$ ). Flash column chromatography [Petrol:EtOAc 49:1] afforded an inseparable mixture of $\mathbf{2 0 g}$ and dibenzylideneacetone ( $42 \mathrm{mg}$, ratio 20g: dba $13: 1$, corresponding to 40.0 mg of $\mathbf{2 0 g}, 52 \%$ ) as a yellow oil. $R_{F} 0.66$ [Petrol:EtOAc 3:1].

IR (film): 3078, 2967, 2926, 2891, 1748, 1667, 1597, $1495 \mathrm{~cm}^{-1}$.

${ }^{1} \mathrm{H}$ NMR (400 MHz, $\left.\mathrm{CDCl}_{3}\right): \delta=8.08(\mathrm{dd}, J=8.5,1.3 \mathrm{~Hz}, 2 \mathrm{H}), 7.54(\mathrm{tt}, J=$ $7.4,1.3 \mathrm{~Hz}, 1 \mathrm{H}), 7.42(\mathrm{t}, J=7.7 \mathrm{~Hz}, 2 \mathrm{H}), 7.24(\mathrm{dd}, J=8.8,7.4 \mathrm{~Hz}, 2 \mathrm{H}), 6.94$ $(\mathrm{tt}, J=7.4,1.0 \mathrm{~Hz}, 1 \mathrm{H}), 6.80(\mathrm{dd}, J=8.8,1.0 \mathrm{~Hz}, 2 \mathrm{H}), 5.54(\mathrm{t}, J=1.4 \mathrm{~Hz}$, $1 \mathrm{H}), 5.24(\mathrm{~s}, 1 \mathrm{H}), 4.77(\mathrm{~d}, J=12.7 \mathrm{~Hz}, 1 \mathrm{H}), 4.57(\mathrm{~d}, J=12.7 \mathrm{~Hz}, 1 \mathrm{H}), 2.86-$ $2.79(\mathrm{~m}, 1 \mathrm{H}), 2.53-2.43(\mathrm{~m}, 2 \mathrm{H}), 2.41-2.30(\mathrm{~m}, 1 \mathrm{H}), 2.08-1.97(\mathrm{~m}, 1 \mathrm{H})$, $1.95-1.82(\mathrm{~m}, 1 \mathrm{H})$.

${ }^{13} \mathrm{C}$ NMR $\left(100 \mathrm{MHz}, \mathrm{CDCl}_{3}\right): \delta=212.3,196.8,158.0,142.2,134.6,133.0$, $130.1,129.4,128.1,121.1,116.8,114.4,70.4,69.0,37.8,34.3,19.4$.

HRMS (ESI): $m / z \quad[\mathrm{M}+\mathrm{Na}]^{+}$calcd for $\mathrm{C}_{21} \mathrm{H}_{20} \mathrm{O}_{3}$ : 343.1305; found: 343.1293.

\section{2-Acetyl-2-(3-phenoxyprop-1-en-2-yl)cyclohexanone (20h): ${ }^{15}$}

Following method A, carbonate $\mathbf{3 1} \mathbf{1}^{15}$ (53.3 mg, $0.24 \mathrm{mmol}$ ) was reacted with phenol $(25 \mathrm{mg}, 0.26 \mathrm{mmol})$. Flash column chromatography
[Petrol:EtOAc 19:1] afforded 20h (50 mg, 77\%) as a clear oil. $R_{F} 0.39$ [Petrol:EtOAc 4:1].

Enantioselective catalysis: carbonate $\mathbf{1 4}^{15}(35.5 \mathrm{mg}, 0.16 \mathrm{mmol})$, $\mathrm{Pd}_{2}(\mathrm{dba})_{3}$ (7.3 mg, $\left.0.008 \mathrm{mmol}\right),(R)$-Xylyl-P-PHOS (35, $7.3 \mathrm{mg}, 0.0096$ $\mathrm{mmol}$ ) and phenol (15 mg, $0.16 \mathrm{mmol}$ ) were added to a dried tube under argon. The tube was fitted with a septum and purged further with argon. Tetrahydrofuran $(1 \mathrm{~mL})$ was added and the mixture was stirred at $60{ }^{\circ} \mathrm{C}$ for 2 hours, then concentrated in vacuo. Flash column chromatography [Petrol:EtOAc 19:1-9:1] afforded 20h (19 mg, 44\%).

Chiral HPLC: AD-H column, $1 \mathrm{~mL} / \mathrm{min}$, [Hexane:IPA 9:1], $t_{\mathrm{A}}$ (major) $=6.0$ $\min , t_{\mathrm{B}}$ (minor) $=6.5 \mathrm{~min}, 19 \%$ ee.

$[\alpha]_{\mathrm{D}^{25}}+0.8\left(c 0.1, \mathrm{CHCl}_{3}, 19 \%\right.$ ee $)$.

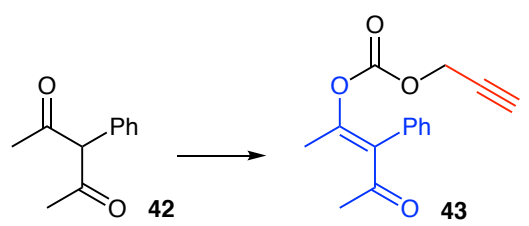

4-0xo-3-phenylpent-2-en-2-yl prop-2-ynyl carbonate (43)

A suspension of sodium hydride (60 wt\% in mineral oil, $74.8 \mathrm{mg}, 1.87$ $\mathrm{mmol})$ in tetrahydrofuran $(15 \mathrm{~mL})$ was cooled to $0{ }^{\circ} \mathrm{C}$. A solution of $\mathbf{4 2}^{24}$ (300 mg, $1.70 \mathrm{mmol})$ in tetrahydrofuran $(5 \mathrm{~mL})$ was added dropwise and the mixture was stirred at $0{ }^{\circ} \mathrm{C}$ for 10 minutes. Propargyl chloroformate (182 $\mu \mathrm{L}, 1.87 \mathrm{mmol}$ ) was added dropwise and the mixture was allowed to warm to room temperature and was stirred at room temperature for 1.5 hours. The reaction was quenched by the addition of aq. $\mathrm{HCl}(1 \mathrm{~N}, 10$ $\mathrm{mL})$ and the mixture was extracted with EtOAc (3 x $25 \mathrm{~mL})$. The combined organic phases were washed with brine $(30 \mathrm{~mL})$, dried $\left(\mathrm{MgSO}_{4}\right)$ and concentrated in vacuo. Flash column chromatography [Petrol:EtOAc 4:1] afforded $43(279 \mathrm{mg}, 57 \%)$ as a pale green solid. $R_{F}$ 0.16 [Petrol:EtOAc 2:1]; m.p. $46-48^{\circ} \mathrm{C}$.

IR (film): 3270, 2989, 2126, 1763, 1686, $1612 \mathrm{~cm}^{-1}$.

${ }^{1} \mathrm{H}$ NMR (400 MHz, $\left.\mathrm{CDCl}_{3}\right): \delta=7.41-7.30(\mathrm{~m}, 3 \mathrm{H}), 7.25-7.21(\mathrm{~m}, 2 \mathrm{H}), 4.81$ $(\mathrm{d}, J=2.8 \mathrm{~Hz}, 2 \mathrm{H}), 2.58(\mathrm{t}, J=2.1 \mathrm{~Hz}, 1 \mathrm{H}), 2.11(\mathrm{~s}, 3 \mathrm{H}), 1.91(\mathrm{~s}, 3 \mathrm{H})$.

${ }^{13} \mathrm{C}$ NMR $\left(100 \mathrm{MHz}, \mathrm{CDCl}_{3}\right): \delta=198.2,151.1,150.7,134.8,131.1,129.3$, 128.8, 128.0, 76.4, 76.1, 55.9, 30.6, 18.4 .

HRMS (ESI): $m / z$ [M+H] ${ }^{+}$calcd for $\mathrm{C}_{15} \mathrm{H}_{14} \mathrm{O}_{4}: 259.0962$; found: 259.0965 .

3-(3-Phenoxyprop-1-en-2-yl)-3-phenylpentane-2,4-dione (20k) and 3-(2-phenoxyallyl)-3-phenylpentane-2,4-dione (21k):

Following method A, carbonate $\mathbf{4 3}$ (62 $\mathrm{mg}, 0.24 \mathrm{mmol})$ was reacted with phenol ( $25 \mathrm{mg}, 0.26 \mathrm{mmol}$ ). Flash column chromatography [Petrol:EtOAc 19:1] afforded an inseparable mixture of $\mathbf{2 0 k}$, dba and $21 \mathbf{k}$ in a 4.0:1.5:1 ratio (29 $\mathrm{mg}$, corresponding to $25.5 \mathrm{mg}$ of $\mathbf{2 0 k}$ and $21 \mathbf{k}, 35 \%$ ) as a yellow oil. $R_{F} 0.48$ [Petrol:EtOAc 4:1].

IR (film): 3014, 2983, 1681, 1627, $1573 \mathrm{~cm}^{-1}$.

${ }^{1} \mathrm{H}$ NMR (400 $\mathrm{MHz}, \mathrm{CDCl}_{3}$, resonances due to $\mathbf{2 1 k}$ annotated by an asterisk): $\delta=7.44-7.18(\mathrm{~m}), 6.94(\mathrm{tt}, J=7.6,1.2 \mathrm{~Hz}), 6.89-6.84(\mathrm{~m})(10 \mathrm{H}$ and $\left.10 \mathrm{H}^{*}\right), 5.85(\mathrm{t}, J=1.6 \mathrm{~Hz}, 1 \mathrm{H}), 5.32(\mathrm{~s}, 1 \mathrm{H}), 4.66(\mathrm{t}, J=0.8 \mathrm{~Hz}, 2 \mathrm{H})$, $4.00\left(\mathrm{~d}, J=2.4 \mathrm{~Hz}, 1 \mathrm{H}^{*}\right), 3.83\left(\mathrm{~d}, J=2.4 \mathrm{~Hz}, 1 \mathrm{H}^{*}\right), 3.35\left(\mathrm{~s}, 2 \mathrm{H}^{*}\right), 2.21(\mathrm{~s}, 6 \mathrm{H}$ and $\left.6 \mathrm{H}^{*}\right)$.

${ }^{13} \mathrm{C}$ NMR $\left(100 \mathrm{MHz} \mathrm{CDCl}_{3}\right): \delta=205.1,204.9,158.8,158.2,143.3,142.9$, $135.6,134.7,130.5,129.5,129.4,128.9,128.4,128.2,128.2,127.5,125.4$, 124.5, 121.5, 121.2, 121.1, 114.6, 74.1, 72.7, 68.9, 38.9, 29.7, 28.1.

HRMS (ESI): $m / z[\mathrm{M}+\mathrm{Na}]^{+}$calcd for $\mathrm{C}_{20} \mathrm{H}_{20} \mathrm{O}_{3}$ : 331.1305; found: 331.1292 .

2-Isobutyryl-2-(3-(4-nitrophenoxy)prop-1-en-2-yl)cyclohexanone (20q) and 2-isobutyryl-2-(2-(4-nitrophenoxy)allyl)cyclohexanone (21q):

Following method A, carbonate $\mathbf{1 4}^{15}$ (60 mg, $0.24 \mathrm{mmol}$ ) was reacted with 4-nitrophenol (36 mg, $0.26 \mathrm{mmol}$ ). Flash column chromatography [Petrol:EtOAc 49:1-19:1] afforded 20q (23 mg, 28\%) as a clear oil, $R_{F}$ 
0.23 [Petrol:EtOAc 4:1], and 21q (18.5 mg, 22\%) as a clear oil, $R_{F} 0.35$ [Petrol:EtOAc 4:1].

20q: IR (film): 3335, 2896, 2829, 1687, $1569 \mathrm{~cm}^{-1}$.

${ }^{1} \mathrm{H}$ NMR (400 MHz, $\mathrm{CDCl}_{3}$ ): $\delta=8.19(\mathrm{~d}, J=9.3 \mathrm{~Hz}, 2 \mathrm{H}), 7.00(\mathrm{~d}, J=9.3 \mathrm{~Hz}$, $2 \mathrm{H}), 5.65(\mathrm{t}, J=1.4 \mathrm{~Hz}, 1 \mathrm{H}), 5.27(\mathrm{~s}, 1 \mathrm{H}), 4.70(\mathrm{dt}, J=12.9 \mathrm{~Hz}, 1.3 \mathrm{~Hz}, 1 \mathrm{H})$, $4.49(\mathrm{~d}, J=12.9 \mathrm{~Hz}, 1 \mathrm{H}), 3.05$ (sept, $J=6.7 \mathrm{~Hz}, 1 \mathrm{H}), 2.60(\mathrm{dt}, J=14.0,6.8$ $\mathrm{Hz}, 1 \mathrm{H}), 2.54-2.43(\mathrm{~m}, 2 \mathrm{H}), 2.16-2.08(\mathrm{~m}, 1 \mathrm{H}), 1.95-1.79(\mathrm{~m}, 3 \mathrm{H}), 1.79-$ $1.68(\mathrm{~m}, 1 \mathrm{H}), 1.11(\mathrm{~d}, J=6.7 \mathrm{~Hz}, 3 \mathrm{H}), 1.06(\mathrm{~d}, J=6.7 \mathrm{~Hz}, 3 \mathrm{H})$.

${ }^{13} \mathrm{C}$ NMR $\left(100 \mathrm{MHz}, \mathrm{CDCl}_{3}\right): \delta=213.5,209.4,163.3,141.7,140.3,125.9$, $118.9,114.7,72.5,69.4,41.2,36.7,32.7,26.8,22.1,20.8,20.7$.

HRMS (ESI): $m / z$ [M+Na ${ }^{+}$calcd for $\mathrm{C}_{19} \mathrm{H}_{23} \mathrm{NO}_{5}$ : 368.1468; found: 368.1464 .

21q: IR (film): 2895, 2828, 1669, 1622, 1586, $1567 \mathrm{~cm}^{-1}$.

${ }^{1} \mathrm{H}$ NMR (400 MHz, $\mathrm{CDCl}_{3}$ ): $\delta=8.22(\mathrm{~d}, J=9.3 \mathrm{~Hz}, 2 \mathrm{H}), 7.09(\mathrm{~d}, J=9.2 \mathrm{~Hz}$, $2 \mathrm{H}), 4.40(\mathrm{~d}, J=2.4 \mathrm{~Hz}, 1 \mathrm{H}), 4.18(\mathrm{~d}, J=2.5 \mathrm{~Hz}, 1 \mathrm{H}), 3.07(\mathrm{~d}, J=15.0 \mathrm{~Hz}$, 1H), 2.97 (sept, $J=6.7 \mathrm{~Hz}, 1 \mathrm{H}), 2.73(\mathrm{~d}, J=15.0 \mathrm{~Hz}, 1 \mathrm{H}), 2.67$ (dtd, $J=$ $13.9,4.0,2.5 \mathrm{~Hz}, 1 \mathrm{H}$ ), 2.54 (dtd, $J=13.9,4.3,1.0 \mathrm{~Hz}, 1 \mathrm{H}$ ), 2.31 (ddd, $J=$ 14.4, 12.0, $5.7 \mathrm{~Hz}, 1 \mathrm{H}), 2.05-1.96(\mathrm{~m}, 1 \mathrm{H}), 1.86-1.77(\mathrm{~m}, 2 \mathrm{H}), 1.75-1.64$ (m, 1H), 1.55-1.45 (m, 1H), $1.05(\mathrm{~d}, J=6.6 \mathrm{~Hz}, 3 \mathrm{H}), 0.99(\mathrm{~d}, J=6.7 \mathrm{~Hz}$, $3 \mathrm{H})$.

${ }^{13} \mathrm{C}$ NMR $\left(100 \mathrm{MHz}, \mathrm{CDCl}_{3}\right): \delta=210.8,208.9,160.0,157.4,143.8,125.7$, $120.5,95.4,66.6,42.3,38.7,36.4,33.7,26.9,22.2,21.2,20.1$.

HRMS (ESI): $m / z$ [M+Na $]^{+}$calcd for $\mathrm{C}_{19} \mathrm{H}_{23} \mathrm{NO}_{5}$ : 368.1468; found: 368.1461.

2-Acetyl-2-(3-(4-nitrophenoxy)prop-1-en-2-yl)-3,4dihydronaphthalen-1(2H)-one (20r) and 2-acetyl-2-(2-(4nitrophenoxy)allyl)-3,4-dihydronaphthalen-1(2H)-one (21r):

Following method A, carbonate $14^{15}$ (65 mg, $0.24 \mathrm{mmol}$ ) was reacted with 4-nitrophenol (36 mg, $0.26 \mathrm{mmol}$ ). Flash column chromatography [Petrol:EtOAc 19:1-9:1-4:1] afforded 20r (35.5 mg, 41\%) as a dark yellow solid, $R_{F} 0.15$ [Petrol:EtOAc 4:1], m.p. $124-126{ }^{\circ} \mathrm{C}$, and $21 \mathrm{r}$ (38.5 mg, 44\%) as a clear oil, $R_{F} 0.30$ [Petrol:EtOAc 4:1].

20r: IR (film): 3009, 2908, 1685, 1647, 1571, 1492, 1477, $1320 \mathrm{~cm}^{-1}$.

1H NMR (400 MHz, $\left.\mathrm{CDCl}_{3}\right): \delta=8.16(\mathrm{~d}, J=9.6 \mathrm{~Hz}, 2 \mathrm{H}), 8.12(\mathrm{~d}, J=9.2 \mathrm{~Hz}$, $1 \mathrm{H}), 7.51(\mathrm{td}, J=5.7,1.6 \mathrm{~Hz}, 1 \mathrm{H}), 7.32(\mathrm{td}, J=7.6,0.8 \mathrm{~Hz}, 1 \mathrm{H}), 7.24(\mathrm{~d}, J=$ $7.6 \mathrm{~Hz}, 1 \mathrm{H}), 6.87(\mathrm{~d}, J=9.2 \mathrm{~Hz}, 2 \mathrm{H}), 5.59(\mathrm{~s}, 1 \mathrm{H}), 5.21(\mathrm{~s}, 1 \mathrm{H}), 4.77(\mathrm{~d}, J=$ $12.0 \mathrm{~Hz}, 1 \mathrm{H}), 4.69(\mathrm{dd}, J=12.4,0.8 \mathrm{~Hz}, 1 \mathrm{H}), 3.00(\mathrm{t}, J=13.6 \mathrm{~Hz}, 2 \mathrm{H}), 2.73$ (dd, $J=14.0,6.4 \mathrm{~Hz}, 1 \mathrm{H}), 2.43-2.37(\mathrm{~m}, 1 \mathrm{H}), 2.36(\mathrm{~s}, 3 \mathrm{H})$.

${ }^{13} \mathrm{C}$ NMR $\left(100 \mathrm{MHz} \mathrm{CDCl}_{3}\right): \delta=205.6,195.8,162.9,143.0,141.8,140.2$, 134.0, 131.9, 128.7, 127.9, 127.0, 125.9, 119.8, 114.6, 70.2, 67.9, 29.6, 28.2, 25.8 .

HRMS (ESI): $m / z \quad[\mathrm{M}+\mathrm{H}]^{+}$calcd for $\mathrm{C}_{21} \mathrm{H}_{19} \mathrm{NO}_{5}$ : 366.1336; found: 366.1333 .

21r: IR (film): 3029, 2888, 2807, 1683, 1648, 1567, 1495, 1467, 1431 $\mathrm{cm}^{-1}$.

${ }^{1} \mathrm{H} \mathrm{NMR}\left(400 \mathrm{MHz}, \mathrm{CDCl}_{3}\right): \delta=8.21(\mathrm{~d}, J=8.4 \mathrm{~Hz}, 2 \mathrm{H}), 8.03(\mathrm{~d}, J=8.0 \mathrm{~Hz}$, $1 \mathrm{H}), 7.50(\mathrm{t}, J=7.6 \mathrm{~Hz}, 1 \mathrm{H}), 7.32(\mathrm{t}, J=7.6 \mathrm{~Hz}, 1 \mathrm{H}), 7.23(\mathrm{~d}, J=7.6 \mathrm{~Hz}, 1 \mathrm{H})$, $7.07(\mathrm{~d}, J=9.2 \mathrm{~Hz}, 2 \mathrm{H}), 4.52(\mathrm{~d}, J=2.4 \mathrm{~Hz}, 1 \mathrm{H}), 4.30(\mathrm{~d}, J=2.4 \mathrm{~Hz}, 1 \mathrm{H})$, $3.27-3.14(\mathrm{~m}, 2 \mathrm{H}), 2.93(\mathrm{dt}, J=17.6,4.0 \mathrm{~Hz}, 1 \mathrm{H}), 2.85(\mathrm{~d}, J=14.8 \mathrm{~Hz}, 1 \mathrm{H})$, $2.80(\mathrm{dt}, J=14.0,4.0 \mathrm{~Hz}, 1 \mathrm{H}), 2.14(\mathrm{~s}, 3 \mathrm{H}), 2.08$ (ddd, $J=16.4,11.2,5.2$ $\mathrm{Hz}, 1 \mathrm{H})$.

${ }^{13} \mathrm{C}$ NMR (100 MHz, $\left.\mathrm{CDCl}_{3}\right): \delta=204.2,196.2,160.1,157.1,143.8,143.7$, 134.1, 131.8, 129.0, 127.9, 126.8, 125.7, 120.0, 96.8, 62.8, 39.3, 29.4, 27.1, 25.8 .

HRMS (ESI): $m / z[\mathrm{M}+\mathrm{Na}]^{+}$calcd for $\mathrm{C}_{21} \mathrm{H}_{19} \mathrm{NO}_{5}$ : 388.1155; found: 388.1148.

2-Acetyl-2-(3-(4-(trifluoromethyl)phenoxy)prop-1-en-2yl)cyclohexan-1-one (20s) and 2-acetyl-2-(2-(4(trifluoromethyl)phenoxy)allyl)cyclohexan-1-one (21s):

Following method A, carbonate $\mathbf{3 1} \mathbf{1}^{15}(53.3 \mathrm{mg}, 0.24 \mathrm{mmol})$ was reacted with 4-(trifluoromethyl)phenol (42 $\mathrm{mg}, 0.26 \mathrm{mmol}$ ). Flash column chromatography [Petrol:EtOAc 19:1-9:1] afforded 20s (26.5 mg, 32\%) as a clear oil, $R_{F} 0.39$ [Petrol:EtOAc 4:1], and an inseparable mixture of $21 \mathrm{~s}$ and dba in a $9.4: 1$ ratio (21.5 mg, corresponding to $20 \mathrm{mg}$ of $21 \mathrm{~s}, 25 \%$ ) as a pale yellow oil, $R_{F} 0.50$ [Petrol:EtOAc 4:1].

20s: IR (film): 3037, 2902, 2824, 1687, 1617, 1589, $1566 \mathrm{~cm}^{-1}$.

${ }^{1} \mathrm{H} \mathrm{NMR}\left(400 \mathrm{MHz}, \mathrm{CDCl}_{3}\right): \delta=7.53(\mathrm{~d}, J=8.4 \mathrm{~Hz}, 2 \mathrm{H}), 6.95(\mathrm{~d}, J=8.4 \mathrm{~Hz}$, $2 \mathrm{H}), 5.64(\mathrm{t}, J=1.2 \mathrm{~Hz}, 1 \mathrm{H}), 5.26(\mathrm{~s}, 1 \mathrm{H}), 4.62(\mathrm{~d}, J=12.0 \mathrm{~Hz}, 1 \mathrm{H}), 4.49$ (dd, $J=12.4,1.2 \mathrm{~Hz}, 1 \mathrm{H}$ ), 2.63-2.49 (m, 2H), 2.45 (dddd, $J=14.8,7.2,3.2$, $1.6 \mathrm{~Hz}, 1 \mathrm{H}), 2.24(\mathrm{~s}, 3 \mathrm{H}), 2.11-2.02(\mathrm{~m}, 1 \mathrm{H}), 1.98-1.74(\mathrm{~m}, 3 \mathrm{H}), 1.73-1.61$ $(\mathrm{m}, 1 \mathrm{H})$.

${ }^{13} \mathrm{C}$ NMR $\left(100 \mathrm{MHz} \mathrm{CDCl}_{3}\right): \delta=209.2,206.7,160.6,141.5,126.9(\mathrm{q}, J=$ $3.7 \mathrm{~Hz}), 123.3$ (q, $J=32.6 \mathrm{~Hz}$ ), 119.4, 114.6, 71.6, 69.4, 40.9, 32.8, 27.1, 27.0, 21.8, (signal due to $\mathrm{CF}_{3}$ not observed).

HRMS (ESI): $m / z$ [M+Na ${ }^{+}$calcd for $\mathrm{C}_{18} \mathrm{H}_{19} \mathrm{~F}_{3} \mathrm{O}_{3}$ : 363.1179; found: 363.1175.

21s: IR (film): 3070, 3018, 2900, 2827, 1670, 1619, $1589 \mathrm{~cm}^{-1}$.

${ }^{1} \mathrm{H}$ NMR (400 MHz, $\left.\mathrm{CDCl}_{3}\right): \delta=7.59(\mathrm{~d}, J=8.4 \mathrm{~Hz}, 2 \mathrm{H}), 7.07(\mathrm{~d}, J=8.0 \mathrm{~Hz}$, $2 \mathrm{H}$ ), 4.23 (d, $J=2.4 \mathrm{~Hz}, 1 \mathrm{H}$ ), 4.00 (d, $J=2.4 \mathrm{~Hz}, 1 \mathrm{H}$ ), 3.19 (d, $J=14.8 \mathrm{~Hz}$, $1 \mathrm{H}), 2.76(\mathrm{dq}, J=14.0,3.6 \mathrm{~Hz}, 1 \mathrm{H}), 2.52(\mathrm{dtd}, J=13.6,4.0,1.6 \mathrm{~Hz}, 1 \mathrm{H})$, $2.50(\mathrm{~d}, J=14.8 \mathrm{~Hz}, 1 \mathrm{H}), 2.24(\mathrm{td}, J=12.8,5.6 \mathrm{~Hz}, 1 \mathrm{H}), 2.13(\mathrm{~s}, 3 \mathrm{H}), 2.09$ $1.98(\mathrm{~m}, 1 \mathrm{H}), 1.89-1.74(\mathrm{~m}, 2 \mathrm{H}), 1.68$ (tt, $J=12.8,4.0 \mathrm{~Hz}, 1 \mathrm{H}$ ), 1.43 (ddd, $J$ $=13.6,12.0,4.4 \mathrm{~Hz}, 1 \mathrm{H})$.

${ }^{13} \mathrm{C}$ NMR $\left(100 \mathrm{MHz} \mathrm{CDCl}_{3}\right): \delta=209.0,204.3,158.2,157.2,127.0(\mathrm{q}, J=$ $3.8 \mathrm{~Hz}), 126.5(\mathrm{q}, J=32.5 \mathrm{~Hz}), 121.1,93.0,66.7,41.9,39.2,34.3,27.4$, 26.7, 22.2, (signal due to $\mathrm{CF}_{3}$ not observed).

HRMS (ESI): $m / z[\mathrm{M}+\mathrm{Na}]^{+}$calcd for $\mathrm{C}_{18} \mathrm{H}_{19} \mathrm{~F}_{3} \mathrm{O}_{3}$ : 363.1179; found: 363.1169.

2-Acetyl-2-(3-(pyridin-3-yloxy)prop-1-en-2-yl)cyclohexan-1-one (20t) and 2-acetyl-2-(2-(pyridin-3-yloxy)allyl)cyclohexan-1-one (21t):

Following method A, carbonate $\mathbf{3 1} \mathbf{1}^{15}$ (53.3 $\mathrm{mg}, 0.24 \mathrm{mmol}$ ) was reacted with 3-hydroxypyridine (25 mg, $0.26 \mathrm{mmol})$. Flash column chromatography [Petrol:EtOAc 2:1-1:1] afforded 20t (21 mg, 32\%) as a brown oil, $R_{F} 0.16$ [Petrol:EtOAc 1:1], and 21t ( $9 \mathrm{mg}, 14 \%$ ) as a dark orange solid, $R_{F} 0.34$ [Petrol:EtOAc 1:1], m.p. $61-63^{\circ} \mathrm{C}$.

20t: IR (film): 2894, 2822, 1687, 1669, $1550 \mathrm{~cm}^{-1}$.

${ }^{1} \mathrm{H}$ NMR (400 MHz, $\left.\mathrm{CDCl}_{3}\right): \delta=8.32-8.24(\mathrm{~m}, 1 \mathrm{H}), 8.21(\mathrm{dd}, J=3.6,2.4 \mathrm{~Hz}$, $1 \mathrm{H}), 7.26-7.21(\mathrm{~m}, 2 \mathrm{H}), 5.64(\mathrm{t}, J=1.2 \mathrm{~Hz}, 1 \mathrm{H}), 5.27(\mathrm{~s}, 1 \mathrm{H}), 4.63(\mathrm{~d}, J=$ $12.4 \mathrm{~Hz}, 1 \mathrm{H}$ ), 4.49 (dd, $J=12.4,1.2 \mathrm{~Hz}, 1 \mathrm{H}), 2.61-2.50(\mathrm{~m}, 2 \mathrm{H}), 2.46$ (ddq, $J=14.0,6.8,1.2 \mathrm{~Hz}, 1 \mathrm{H}), 2.23(\mathrm{~s}, 3 \mathrm{H}), 2.06$ (dddd, $J=14.4,9.6,4.0,0.8 \mathrm{~Hz}$, 1H), 1.97-1.86 (m, 1H), 1.86-1.74 (m, 2H), 1.72-1.60 (m, 1H).

${ }^{13} \mathrm{C}$ NMR $\left(100 \mathrm{MHz}, \mathrm{CDCl}_{3}\right): \delta=209.1,206.8,154.6,142.1,141.4,137.8$, 124.5, 121.5, 119.4, 71.7, 69.5, 40.9, 32.8, 27.0, 26.9, 21.9.

HRMS (ESI): $m / z[\mathrm{M}+\mathrm{H}]^{+}$calcd for $\mathrm{C}_{16} \mathrm{H}_{19} \mathrm{NO}_{3}$ : 274.1438; found: 274.1429.

21t: IR (film): 2898, 2824, 1672, $1618 \mathrm{~cm}^{-1}$.

${ }^{1} \mathrm{H} \mathrm{NMR}\left(400 \mathrm{MHz}, \mathrm{CDCl}_{3}\right.$ ): $\delta=8.41$ (br s, $1 \mathrm{H}$ ), 8.32 (br s, $1 \mathrm{H}$ ), 7.33 (ddd, $J$ $=8.4,2.8,1.6 \mathrm{~Hz}, 1 \mathrm{H}), 7.30-7.26(\mathrm{~m}, 1 \mathrm{H}), 4.17(\mathrm{~d}, J=2.4 \mathrm{~Hz}, 1 \mathrm{H}), 3.87(\mathrm{~d}, J$ $=2.4 \mathrm{~Hz}, 1 \mathrm{H}), 3.21(\mathrm{~d}, J=14.8 \mathrm{~Hz}, 1 \mathrm{H}), 2.76(\mathrm{dq}, J=14.0,3.6 \mathrm{~Hz}, 1 \mathrm{H}), 2.53$ (dtd, $J=13.6,4.0,1.6 \mathrm{~Hz}, 1 \mathrm{H}), 2.51(\mathrm{~d}, J=14.8 \mathrm{~Hz}, 1 \mathrm{H}), 2.24$ (ddd, $J=14.0$, 13.2, 6.4 Hz, 1H), $2.14(\mathrm{~s}, 3 \mathrm{H}), 2.09-1.99(\mathrm{~m}, 1 \mathrm{H}), 1.92-1.74(\mathrm{~m}, 2 \mathrm{H}), 1.68$ (qt, $J=12.8,4.0 \mathrm{~Hz}, 1 \mathrm{H}), 1.43(\mathrm{ddd}, J=14.0,12.0,4.8 \mathrm{~Hz}, 1 \mathrm{H})$.

${ }^{13} \mathrm{C}$ NMR $\left(100 \mathrm{MHz}, \mathrm{CDCl}_{3}\right): \delta=209.0,204.2,159.0,150.9,145.9,143.8$, 128.8, 124.1, 91.7, 66.7, 41.9, 39.5, 34.3, 27.4, 26.7, 22.2.

HRMS (ESI): $m / z[\mathrm{M}+\mathrm{H}]^{+}$calcd for $\mathrm{C}_{16} \mathrm{H}_{19} \mathrm{NO}_{3}$ : 274.1438; found: 274.1436.

2-Acetyl-2-(3-(3-chlorophenoxy)prop-1-en-2-yl)cyclohexan-1-one (20u) and 2-acetyl-2-(2-(3-chlorophenoxy)allyl)cyclohexan-1-one (21u):

Following method A, carbonate $\mathbf{3 1} \mathbf{1}^{15}$ (53.3 mg, $0.24 \mathrm{mmol}$ ) was reacted with 3-chlorophenol (33.4 $\mathrm{mg}, 0.26 \mathrm{mmol})$. Flash column chromatography [Petrol:EtOAc 19:1-9:1] afforded 20u (34 mg, 46\%) as a pale yellow oil, $R_{F} 0.36$ [Petrol:EtOAc 4:1], and an inseparable mixture of 


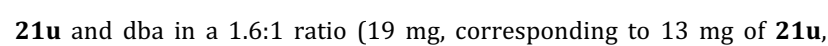
$18 \%$ ) as a yellow oil, $R_{F} 0.46$ [Petrol:EtOAc 4:1].

20u: IR (film): 3024, 2899, 2823, 1687, 1618, $1570 \mathrm{~cm}^{-1}$.

${ }^{1} \mathrm{H} \mathrm{NMR}\left(400 \mathrm{MHz}, \mathrm{CDCl}_{3}\right.$ ): $\delta=7.17(\mathrm{t}, J=8.4 \mathrm{~Hz}, 1 \mathrm{H}), 6.92(\mathrm{ddd}, J=7.6$, $1.6,0.8 \mathrm{~Hz}, 1 \mathrm{H}), 6.87,(\mathrm{t}, J=2.0 \mathrm{~Hz}, 1 \mathrm{H}), 6.76(\mathrm{ddd}, J=8.4,2.4,0.8 \mathrm{~Hz}, 1 \mathrm{H}$ ), $5.64(\mathrm{t}, J=0.8 \mathrm{~Hz}, 1 \mathrm{H}), 5.24(\mathrm{~s}, 1 \mathrm{H}), 4.55(\mathrm{~d}, J=12.0 \mathrm{~Hz}, 1 \mathrm{H}), 4.44(\mathrm{dd}, J=$ 12.0, $0.8 \mathrm{~Hz}, 1 \mathrm{H}$ ), 2.65-2.47 (m, 2H), 2.43 (dddd, $J=14.4,7.6,3.2,1.2 \mathrm{~Hz}$, 1H), 2.32 (s, 3H), 2.06 (dddd, $J=14.4,8.8,3.2,1.2 \mathrm{~Hz}, 1 \mathrm{H}), 1.95-1.61$ (m, $4 \mathrm{H})$.

${ }^{13} \mathrm{C}$ NMR $\left(100 \mathrm{MHz}, \mathrm{CDCl}_{3}\right): \delta=209.3,206.7,158.8,141.6,134.8,130.2$, $121.3,119.5,115.0,113.0,71.6,69.4,40.8,32.6,27.1$ (2C), 21.8.

HRMS (ESI): $m / z[\mathrm{M}+\mathrm{H}]^{+}$calcd for $\mathrm{C}_{17} \mathrm{H}_{19} \mathrm{ClO}_{3}$ : 307.1095; found: 307.1094.

21u: IR (film): 2890, 2806, 1671, 1626, $1566 \mathrm{~cm}^{-1}$.

${ }^{1} \mathrm{H}$ NMR (400 MHz, $\mathrm{CDCl}_{3}$ ): $\delta=7.25(\mathrm{t}, J=8.4 \mathrm{~Hz}, 1 \mathrm{H}$ ), 7.11 (ddd, $J=8.0$, $2.0,1.2 \mathrm{~Hz}, 1 \mathrm{H}), 6.98(\mathrm{t}, J=2.0 \mathrm{~Hz}, 1 \mathrm{H}), 6.87(\mathrm{ddd}, J=8.0,2.4,0.8 \mathrm{~Hz}, 1 \mathrm{H}$ ), $4.15(\mathrm{~d}, J=2.4 \mathrm{~Hz}, 1 \mathrm{H}), 3.93(\mathrm{~d}, J=2.4 \mathrm{~Hz}, 1 \mathrm{H}), 3.18(\mathrm{~d}, J=14.8 \mathrm{~Hz}, 1 \mathrm{H})$, $2.75(\mathrm{dq}, J=14.0,3.6 \mathrm{~Hz}, 1 \mathrm{H}), 2.52(\mathrm{dtd}, J=13.6,3.6,1.2 \mathrm{~Hz}, 1 \mathrm{H}), 2.47$ (d, $J=14.8 \mathrm{~Hz}, 1 \mathrm{H}), 2.24(\mathrm{td}, J=13.6,5.6 \mathrm{~Hz}, 1 \mathrm{H}), 2.13(\mathrm{~s}, 3 \mathrm{H}), 2.08-1.99(\mathrm{~m}$, $1 \mathrm{H}), 1.90-1.73(\mathrm{~m}, 2 \mathrm{H}), 1.67$ (tt, $J=12.8,4.0 \mathrm{~Hz}, 1 \mathrm{H}$ ), 1.42 (ddd, $J=14.0$, $12.4,4.4 \mathrm{~Hz}, 1 \mathrm{H})$.

${ }^{13} \mathrm{C}$ NMR $\left(100 \mathrm{MHz}, \mathrm{CDCl}_{3}\right): \delta=209.1,204.2,158.6,155.0,134.8,130.4$ $124.8,121.7,119.6,91.8,66.7,41.9,39.2,34.2,27.4,26.7,22.2$.

HRMS (ESI): $m / z$ [M+Na] ${ }^{+}$calcd for $\mathrm{C}_{17} \mathrm{H}_{19} \mathrm{ClO}_{3}$ : 329.0915; found: 329.0911.

2-Acetyl-2-(3-(2-chlorophenoxy)prop-1-en-2-yl)cyclohexan-1-one (20v) and 2-acetyl-2-(2-(2-chlorophenoxy)allyl)cyclohexan-1-one (21v):

Following method A, carbonate $\mathbf{3 1}^{15}$ (53.3 mg, $0.24 \mathrm{mmol}$ ) was reacted with 2-chlorophenol ( $27 \mu \mathrm{L}, 0.26 \mathrm{mmol}$ ). Flash column chromatography [Petrol:EtOAc 19:1-9:1] afforded 20v (39 mg, 53\%) as a yellow oil, $R_{F}$ 0.28 [Petrol:EtOAc 4:1], and an inseparable mixture of $\mathbf{2 1 v}$ and dba in a $1.2: 1$ ratio ( $23 \mathrm{mg}$, corresponding to $12 \mathrm{mg}$ of $21 \mathrm{v}, 16 \%$ ) as a yellow oil, $R_{F} 0.40$ [Petrol:EtOAc 4:1].

20v: IR (film): 3020, 2900, 2822, 1673, $1564 \mathrm{~cm}^{-1}$.

${ }^{1} \mathrm{H} \mathrm{NMR}\left(400 \mathrm{MHz}, \mathrm{CDCl}_{3}\right): \delta=7.33(\mathrm{dd}, J=8.0,1.6 \mathrm{~Hz}, 1 \mathrm{H}), 7.19(\mathrm{ddd}, J=$ 8.4, 7.6, $1.6 \mathrm{~Hz}, 1 \mathrm{H}), 6.96(\mathrm{dd}, J=8.4,1.6 \mathrm{~Hz}, 1 \mathrm{H}), 6.88(\mathrm{td}, J=7.6,1.2 \mathrm{~Hz}$, $1 \mathrm{H}), 5.73(\mathrm{t}, J=1.2 \mathrm{~Hz}, 1 \mathrm{H}), 5.26(\mathrm{~s}, 1 \mathrm{H}), 4.64(\mathrm{~d}, J=12.4 \mathrm{~Hz}, 1 \mathrm{H}), 4.47$ (dd, $J=12.4,0.8 \mathrm{~Hz}, 1 \mathrm{H}), 2.64-2.43(\mathrm{~m}, 3 \mathrm{H}), 2.27(\mathrm{~s}, 3 \mathrm{H}), 2.16-2.07(\mathrm{~m}$, 1H), $1.96-1.75(\mathrm{~m}, 3 \mathrm{H}), 1.73-1.61(\mathrm{~m}, 1 \mathrm{H})$.

${ }^{13} \mathrm{C}$ NMR $\left(100 \mathrm{MHz} \mathrm{CDCl}_{3}\right): \delta=209.2,206.8,153.7,141.3,130.2,127.7$, $122.7,121.6,119.7,113.4,71.8,69.7,40.9,32.7,27.1,27.0,21.9$.

HRMS (ESI): $m / z[\mathrm{M}+\mathrm{H}]^{+}$calcd for $\mathrm{C}_{17} \mathrm{H}_{19} \mathrm{ClO}_{3}$ : 307.1095; found: 307.1088.

21v: IR (film): 3015, 2897, 2824, 1672, 1626, 1596, $1567 \mathrm{~cm}^{-1}$.

${ }^{1} \mathrm{H}$ NMR (400 MHz, $\left.\mathrm{CDCl}_{3}\right): \delta=7.38(\mathrm{dd}, J=8.0,1.6 \mathrm{~Hz}, 1 \mathrm{H}), 7.23$ (ddd, $J=$ 8.0, 7.6, 1.6 Hz, 1H), 7.12-7.06 (m, 1H), $7.03(\mathrm{dd}, J=8.0,1.6 \mathrm{~Hz}, 1 \mathrm{H}), 4.11$ $(\mathrm{d}, J=2.4 \mathrm{~Hz}, 1 \mathrm{H}), 3.76(\mathrm{~d}, J=2.4 \mathrm{~Hz}, 1 \mathrm{H}), 3.24(\mathrm{~d}, J=15.2 \mathrm{~Hz}, 1 \mathrm{H}), 2.80$ (dq, $J=14.0,4.0 \mathrm{~Hz}, 1 \mathrm{H}), 2.57$ (d, $J=14.8 \mathrm{~Hz}, 1 \mathrm{H}), 2.52(\mathrm{dtd}, J=14.0,4.0$, $1.6 \mathrm{~Hz}, 1 \mathrm{H}$ ), 2.25 (ddd, $J=13.6,12.8,5.6 \mathrm{~Hz}, 1 \mathrm{H}$ ), 2.18 (s, 3H), 2.08-1.98 (m, 1H), 1.95-1.75 (m, 2H), 1.68 (qt, $J=12.8,4.0 \mathrm{~Hz}, 1 \mathrm{H}$ ), 1.50 (ddd, $J=$ $14.0,12.4,4.4 \mathrm{~Hz}, 1 \mathrm{H})$.

${ }^{13} \mathrm{C}$ NMR $\left(100 \mathrm{MHz}, \mathrm{CDCl}_{3}\right): \delta=209.0,204.6,157.8,150.2,130.5,128.0$ $127.0,125.8,123.3,90.6,66.7,41.7,39.1,34.1,27.3,26.7,22.2$.

HRMS (ESI): $m / z$ [M+Na] ${ }^{+}$calcd for $\mathrm{C}_{17} \mathrm{H}_{19} \mathrm{ClO}_{3}$ : 329.0915; found: 329.0905 .

2-Acetyl-2-(3-(2-bromophenoxy)prop-1-en-2-yl)cyclohexan-1-one (20w) and 2-acetyl-2-(2-(2-bromophenoxy)allyl)cyclohexan-1-one (21w):

Following method A, carbonate $\mathbf{3 1}^{15}(53.3 \mathrm{mg}, 0.24 \mathrm{mmol})$ was reacted with 2-bromophenol ( $30 \mu \mathrm{L}, 0.26 \mathrm{mmol})$. Flash column chromatography [Petrol:EtOAc 19:1-9:1] afforded 20w (41 mg, 49\%) as a pale yellow oil,
$R_{F} 0.29$ [Petrol:EtOAc 4:1], and an inseparable mixture of $\mathbf{2 1 w}$ and dba in a $1.8: 1$ ratio ( $21 \mathrm{mg}$, corresponding to $9.5 \mathrm{mg}$ of $21 \mathrm{w}, 11 \%$ ) as a yellow solid, $R_{F} 0.40$ [Petrol:EtOAc 4:1], m.p. $46-49^{\circ} \mathrm{C}$.

20w: IR (film): 2898, 2822, $1673 \mathrm{~cm}^{-1}$.

${ }^{1} \mathrm{H} \mathrm{NMR}\left(400 \mathrm{MHz}, \mathrm{CDCl}_{3}\right.$ ): $\delta=7.51(\mathrm{dd}, J=8.0,1.6 \mathrm{~Hz}, 1 \mathrm{H}), 7.24$ (ddd, $J=$ 8.4, 7.6, $1.6 \mathrm{~Hz}, 1 \mathrm{H}), 6.93(\mathrm{dd}, J=8.4,1.6 \mathrm{~Hz}, 1 \mathrm{H}), 6.83(\mathrm{td}, J=7.6,1.6 \mathrm{~Hz}$, $1 \mathrm{H}), 5.76(\mathrm{t}, J=1.2 \mathrm{~Hz}, 1 \mathrm{H}), 5.26(\mathrm{~s}, 1 \mathrm{H}), 4.63(\mathrm{~d}, J=12.4 \mathrm{~Hz}, 1 \mathrm{H}), 4.45(\mathrm{~d}$, $J=12.4 \mathrm{~Hz}, 1 \mathrm{H}), 2.64-2.44(\mathrm{~m}, 3 \mathrm{H}), 2.27$ (s, 3H), 2.17-2.07 (m, 1H), 1.96$1.75(\mathrm{~m}, 3 \mathrm{H}), 1.73-1.60(\mathrm{~m}, 1 \mathrm{H})$.

${ }^{13} \mathrm{C}$ NMR $\left(100 \mathrm{MHz}, \mathrm{CDCl}_{3}\right): \delta=209.1,206.9,154.6,141.1,133.3,128.4$, 122.1, 119.6, 113.3, 111.9, 71.8, 69.6, 40.9, 32.8, 27.1, 27.0, 21.9.

HRMS (ESI): $m / z[\mathrm{M}+\mathrm{H}]^{+}$calcd for $\mathrm{C}_{17} \mathrm{H}_{19} \mathrm{BrO}_{3}$ : 351.0590; found: 351.0580 .

21w: IR (film): 2895, 1672, $1596 \mathrm{~cm}^{-1}$.

${ }^{1} \mathrm{H} \mathrm{NMR}\left(400 \mathrm{MHz}, \mathrm{CDCl}_{3}\right): \delta=7.55(\mathrm{dd}, J=8.0,1.6 \mathrm{~Hz}, 1 \mathrm{H}), 7.30-7.25(\mathrm{~m}$, $1 \mathrm{H}), 7.06-6.99(\mathrm{~m}, 2 \mathrm{H}), 4.13(\mathrm{~d}, J=2.4 \mathrm{~Hz}, 1 \mathrm{H}), 3.77(\mathrm{~d}, J=2.4 \mathrm{~Hz}, 1 \mathrm{H})$, $3.26(\mathrm{~d}, J=14.8 \mathrm{~Hz}, 1 \mathrm{H}), 2.81(\mathrm{dq}, J=14.0,3.6 \mathrm{~Hz}, 1 \mathrm{H}), 2.57$ (d, $J=14.8$ $\mathrm{Hz}, 1 \mathrm{H}), 2.52$ (dtd, $J=14.0,4.0,1.6 \mathrm{~Hz}, 1 \mathrm{H}), 2.31-2.19(\mathrm{~m}, 1 \mathrm{H}), 2.19$ (s, $3 \mathrm{H}), 2.10-1.98(\mathrm{~m}, 1 \mathrm{H}), 1.95-1.61(\mathrm{~m}, 3 \mathrm{H}), 1.51$ (ddd, $J=14.0,12.4,4.4$ $\mathrm{Hz}, 1 \mathrm{H})$.

${ }^{13} \mathrm{C}$ NMR $\left(100 \mathrm{MHz}, \mathrm{CDCl}_{3}\right): \delta=209.0,204.6,157.8,151.4,133.5,128.7$, $126.1,123.3,116.2,90.8,66.8,41.7,39.2,34.2,27.3,26.8,22.2$.

HRMS (ESI): $m / z[\mathrm{M}+\mathrm{Na}]^{+}$calcd for $\mathrm{C}_{17} \mathrm{H}_{19} \mathrm{BrO}_{3}$ : 373.0410; found: 373.0399.

3-(3-(1-Isobutyryl-2-oxocyclohexyl)prop-1-en-2-yl)-3methylpentane-2,4-dione (23b):

Following method B, carbonate $\mathbf{1 4}^{21}(47.1 \mathrm{mg}, 0.24 \mathrm{mmol})$ was reacted with 2-isobutyrylcyclohexanone ( $40 \mu \mathrm{L}, 0.24 \mathrm{mmol})$. Flash column chromatography [Petrol:EtOAc 9:1] afforded 23b (36 mg, 47\%) as a yellow solid. $R_{F} 0.25$ [Petrol:EtOAc 4:1]; m.p. $40-42{ }^{\circ} \mathrm{C}$.

IR (film): 2972, 2931, 2875, 1694, $1641 \mathrm{~cm}^{-1}$.

${ }^{1} \mathrm{H}$ NMR (400 MHz, $\left.\mathrm{CDCl}_{3}\right): \delta=5.02(\mathrm{q}, J=1.2 \mathrm{~Hz}, 1 \mathrm{H}), 4.87(\mathrm{q}, J=1.4 \mathrm{~Hz}$, 1H), 3.01 (sept, $J=6.6 \mathrm{~Hz}, 1 \mathrm{H}), 2.54-2.39(\mathrm{~m}, 5 \mathrm{H}), 2.18(\mathrm{~s}, 3 \mathrm{H}), 2.17$ (s, $3 \mathrm{H}), 1.79-1.60(\mathrm{~m}, 5 \mathrm{H}), 1.55(\mathrm{~s}, 3 \mathrm{H}), 1.10(\mathrm{~d}, J=7.1 \mathrm{~Hz}, 3 \mathrm{H}), 0.98(\mathrm{~d}, J=$ $6.2 \mathrm{~Hz}, 3 \mathrm{H})$.

${ }^{13} \mathrm{C}$ NMR $\left(100 \mathrm{MHz}, \mathrm{CDCl}_{3}\right): \delta=214.8,209.9,207.6,207.4,141.4,116.9$, $71.9,67.6,41.5,36.0,35.7,34.3,27.2,27.1,27.1,22.0,21.0,20.6,18.8$.

HRMS (ESI): $m / z$ [M+H] ${ }^{+}$calcd for $\mathrm{C}_{19} \mathrm{H}_{28} \mathrm{O}_{4}: 321.2060$; found: 321.2047 .

3-(3-(2-Acetyl-1-oxo-1,2,3,4-tetrahydronaphthalen-2-yl)prop-1-en2-yl)-3-methylpentane-2,4-dione (23c): ${ }^{21}$

Carbonate $14^{21}$ (23.5 mg, $\left.0.12 \mathrm{mmol}\right), \mathrm{Pd}_{2}(\mathrm{dba})_{3}(5.5 \mathrm{mg}, 0.006 \mathrm{mmol})$, DPEphos (6.5 mg, $0.012 \mathrm{mmol}$ ) and 2-acetyl-1-tetralone (26.7 mg, 0.12 mmol) were added to a dried tube under argon. The tube was fitted with a septum and purged further with argon. 1,4-Dioxane $(1.5 \mathrm{~mL})$ was added and the sealed tube was added to an oil bath preheated to $80{ }^{\circ} \mathrm{C}$. The mixture was stirred at $80{ }^{\circ} \mathrm{C}$ for 2 hours, then cooled to room temperature and concentrated in vacuo. Flash column chromatography [Petrol:EtOAc 4:1] afforded an inseparable mixture of 23c and homocoupled 14 in a $14: 1$ ratio (34.8 $\mathrm{mg}$, corresponding to $32 \mathrm{mg}$ of $\mathbf{2 3 c}$, $79 \%$ ) as a yellow oil. $R_{F} 0.33$ [Petrol:EtOAc 4:1].

Enantioselective catalysis: carbonate $\mathbf{1 4}^{21}(31.3 \mathrm{mg}, 0.16 \mathrm{mmol})$, $\mathrm{Pd}_{2}(\mathrm{dba})_{3}$ (7.3 mg, $\left.0.008 \mathrm{mmol}\right),(R)$-Tol-BINAP (37, $6.5 \mathrm{mg}, 0.0096$ $\mathrm{mmol}$ ) and 2-acetyl-1-tetralone (30 mg, $0.16 \mathrm{mmol})$ were added to a dried tube under argon. The tube was fitted with a septum and purged further with argon. 1,4-Dioxane (1 mL) was added and the mixture was stirred at room temperature for 16 hours, then concentrated in vacuo. Flash column chromatography [Petrol:EtOAc 9:1-4:1] afforded 23c (37 $\mathrm{mg}, 68 \%$ ).

Chiral HPLC: OD-H column, $1 \mathrm{~mL} / \mathrm{min}$, [Hexane:IPA 9:1], $t_{\mathrm{A}}($ minor) $=$ $11.2 \mathrm{~min}, t_{\mathrm{B}}$ (minor) $=12.9 \mathrm{~min}, 27 \%$ ee.

$[\alpha]_{\mathrm{D}}^{25}+1.4\left(c 0.1, \mathrm{CHCl}_{3}, 27 \%\right.$ ee $)$. 
3-(2-(2-Acetyl-1-oxo-1,2,3,4-tetrahydronaphthalen-2-yl)allyl)-3methylpentane-2,4-dione $(23 \mathrm{~g}):{ }^{21}$

Following method B, carbonate $\mathbf{1 4}^{21}(64.8 \mathrm{mg}, 0.24 \mathrm{mmol}$ ) was reacted with 3-methyl-2,4-pentanedione (28 $\mu \mathrm{L}, 0.24 \mathrm{mmol})$. Flash column chromatography [Petrol:EtOAc 4:1] afforded 23g (58 mg, 71\%) as a yellow oil. $R_{F} 0.34$ [Petrol:EtOAc 4:1].

Enantioselective catalysis: carbonate $\mathbf{1 4}^{21}(43.2 \mathrm{mg}, 0.16 \mathrm{mmol})$, $\mathrm{Pd}_{2}(\mathrm{dba})_{3}(7.3 \mathrm{mg}, 0.008 \mathrm{mmol}),(R)$-Xylyl-P-PHOS (35, 7.3 mg, 0.0096 mmol) and 3-methyl-2,4-pentanedione $(19 \mu \mathrm{L}, 0.16 \mathrm{mmol})$ were added to a dried tube under argon. The tube was fitted with a septum and purged further with argon. Tetrahydrofuran $(1 \mathrm{~mL})$ was added and the mixture was stirred at $60{ }^{\circ} \mathrm{C}$ for 2 hours, then concentrated in vacuo. Flash column chromatography [Petrol:EtOAc 9:1-4:1] afforded 23g (30 $\mathrm{mg}, 57 \%)$.

Chiral HPLC: AD-H column, $1 \mathrm{~mL} / \mathrm{min}$, [Hexane:IPA 9:1], $t_{\mathrm{A}}$ (minor) $=$ $10.7 \mathrm{~min}, t_{\mathrm{B}}$ (major) $=12.6 \mathrm{~min}, 21 \%$ ee.

$[\alpha]_{\mathrm{D}^{25}}-1.3\left(c 0.1, \mathrm{CHCl}_{3}, 21 \%\right.$ ee).

3,6-Diacetyl-3-benzyl-6-methyl-4-methyleneoctane-2,7-dione (23h):

Following method B, carbonate $\mathbf{1 4}^{15}(65.3 \mathrm{mg}, 0.24 \mathrm{mmol})$ was reacted with 3-methyl-2,4-pentanedione (28 $\mu \mathrm{L}, 0.24 \mathrm{mmol})$. Flash column chromatography [Petrol:EtOAc 9:1-4:1] afforded an inseparable mixture of $\mathbf{2 3 h}$ and homo-coupled $\mathbf{1 4}$ in a 6.5:1 ratio $(21 \mathrm{mg}$, corresponding to $17.5 \mathrm{mg}$ of $\mathbf{2 3 h}, 21 \%$ ) as a yellow solid. $R_{F} 0.37$ [Petrol:EtOAc 4:1]; m.p. $70-72{ }^{\circ} \mathrm{C}$

IR (film): 3384, 2993, 2927, 1692, 1641, $1500 \mathrm{~cm}^{-1}$.

${ }^{1} \mathrm{H}$ NMR $\left(400 \mathrm{MHz}, \mathrm{CDCl}_{3}\right): \delta=7.24-7.17(\mathrm{~m}, 3 \mathrm{H}), 7.06(\mathrm{dd}, J=7.7,1.5 \mathrm{~Hz}$, $2 \mathrm{H}), 5.18(\mathrm{q}, J=1.4 \mathrm{~Hz}, 1 \mathrm{H}), 4.91(\mathrm{q}, J=1.9 \mathrm{~Hz}, 1 \mathrm{H}), 3.47(\mathrm{~s}, 2 \mathrm{H}), 2.64(\mathrm{t}, J$ $=1.7 \mathrm{~Hz}, 2 \mathrm{H}), 2.15(\mathrm{~s}, 6 \mathrm{H}), 2.11(\mathrm{~s}, 6 \mathrm{H}), 1.41(\mathrm{~s}, 3 \mathrm{H})$.

${ }^{13} \mathrm{C}$ NMR $\left(100 \mathrm{MHz}, \mathrm{CDCl}_{3}\right): \delta=206.9,205.8,141.2,136.1,129.7,128.4$, $127.0,117.5,78.0,66.0,37.8,35.6,28.4,26.2,18.0$.

HRMS (ESI): $m / z$ [M+H] $]^{+}$calcd for $\mathrm{C}_{21} \mathrm{H}_{26} \mathrm{O}_{4}: 343.1904$; found: 343.1898 .

\section{3,6-Diacetyl-3-methyl-4-methylene-6-phenyloctane-2,7-dione} (23k):

Following method B, carbonate $\mathbf{1 4}^{21}(47.1 \mathrm{mg}, 0.24 \mathrm{mmol}$ ) was reacted with 3-phenyl-2,4-pentanedione ( $42 \mathrm{mg}, 0.24 \mathrm{mmol}$ ). Flash column chromatography [Petrol:EtOAc 9:1-4:1] afforded an inseparable mixture of 23k and homo-coupled 14 in a 4.8:1 ratio (35 $\mathrm{mg}$, corresponding to $28.2 \mathrm{mg}$ of $\mathbf{2 3 k}, 36 \%$ ) as a red oil. $R_{F} 0.22$ [Petrol:EtOAc 4:1].

IR (film): 3058, 2983, 2926, 1692, 1641, $1500 \mathrm{~cm}^{-1}$.

$\left.{ }^{1} \mathrm{H} \mathrm{NMR} \mathrm{(400} \mathrm{MHz}, \mathrm{CDCl}_{3}\right): \delta=7.36-7.27(\mathrm{~m}, 5 \mathrm{H}), 5.08(\mathrm{q}, J=1.7 \mathrm{~Hz}, 1 \mathrm{H})$, $4.89(\mathrm{q}, J=1.9 \mathrm{~Hz}, 1 \mathrm{H}), 3.03(\mathrm{t}, J=2.0 \mathrm{~Hz}, 2 \mathrm{H}), 2.21(\mathrm{~s}, 6 \mathrm{H}), 2.20(\mathrm{~s}, 6 \mathrm{H})$ $1.61(\mathrm{~s}, 3 \mathrm{H})$.

${ }^{13} \mathrm{C}$ NMR $\left(100 \mathrm{MHz}, \mathrm{CDCl}_{3}\right): \delta=207.5,205.8,141.1,136.1,129.0,128.2$, 128.0, 117.1, 72.8, 71.8, 35.2, 28.1, 27.0, 19.0 .

HRMS (ESI): $m / z$ [M+H] $]^{+}$calcd for $\mathrm{C}_{20} \mathrm{H}_{24} \mathrm{O}_{4}: 329.1747$; found: 329.1750 .<smiles>CC(CC1(C)C(=O)CCCC1=O)C1(C)C(=O)CCCC1=O</smiles>

23lb

2,2'-(Prop-2-ene-1,2-diyl)bis(2-methylcyclohexane-1,3-dione) (23lb):

Following method B, carbonate $\mathbf{1 4}^{21}(47.1 \mathrm{mg}, 0.24 \mathrm{mmol}$ ) was reacted with 2-methyl-1,3-cyclohexadione $(30.2 \mathrm{mg}, 0.24 \mathrm{mmol})$. Flash column chromatography [Petrol:EtOAc 4:1] afforded an inseparable mixture of homo-coupled 22 (23lb), 23l, its regioisomer 23q, and homo-coupled 14 in a 9.0:4.0:1.2:1 ratio (39 $\mathrm{mg}$, corresponding to $20 \mathrm{mg}$ of $23 \mathrm{lb}, 27 \%$ ) as an orange solid. $R_{F} 0.29$ [Petrol:EtOAc 9:1-4:1]; m.p. 63-65 ${ }^{\circ} \mathrm{C}$.

IR (film): 3368, 2939, 1723, 1686, $1638 \mathrm{~cm}^{-1}$.
${ }^{1} \mathrm{H}$ NMR ( $400 \mathrm{MHz}, \mathrm{CDCl}_{3}$, resonances due to 23lb quoted): $\delta=4.67$ (q, $J$ $=1.5 \mathrm{~Hz}, 1 \mathrm{H}), 4.11(\mathrm{q}, J=1.5 \mathrm{~Hz}, 1 \mathrm{H}), 2.96-2.87(\mathrm{~m}, 2 \mathrm{H}), 2.84-2.75(\mathrm{~m}$, $2 \mathrm{H}), 2.72-2.57(\mathrm{~m}, 3 \mathrm{H}), 2.54-2.50(\mathrm{~m}, 1 \mathrm{H}), 2.48(\mathrm{t}, J=1.5 \mathrm{~Hz}, 2 \mathrm{H}), 2.18-$ $2.13(\mathrm{~m}, 2 \mathrm{H}), 1.60-1.58(\mathrm{~m}, 2 \mathrm{H}), 1.33-1.31(\mathrm{~m}, 6 \mathrm{H})$.

${ }^{13} \mathrm{C}$ NMR (100 $\mathrm{MHz}, \mathrm{CDCl}_{3}$, resonances due to 23lb quoted): $\delta=209.1$, 208.1, 144.9, 113.0, 73.5, 63.2, 38.7, 37.5, 36.0, 26.7, 17.5, 17.5, 17.4.

HRMS (ESI): $m / z$ [M+H] ${ }^{+}$calcd for $\mathrm{C}_{17} \mathrm{H}_{22} \mathrm{O}_{4}: 291.1591$; found: 291.1580 .

3-Acetyl-6-(1-hydroxyethylidene)-3-methyl-4-methyleneoctane2,7-dione $(23 \mathrm{~m})$ :

Following method B, carbonate $\mathbf{1 4}^{21}(47.1 \mathrm{mg}, 0.24 \mathrm{mmol})$ was reacted with acetylacetone $(25 \mu \mathrm{L}, 0.24 \mathrm{mmol})$. Flash column chromatography [Petrol:EtOAc 4:1] afforded an inseparable mixture of $\mathbf{2 3 m}$ and homocoupled 14 in a $10: 1$ ratio (37 mg, corresponding to $33.6 \mathrm{mg}$ of $\mathbf{2 3 m}$, $56 \%$ ) as a yellow solid. $R_{F} 0.27$ [Petrol:EtOAc 9:1-4:1]; m.p. $63-65^{\circ} \mathrm{C}$.

IR (film): 2983, 2926, 1704, 1639, $1562 \mathrm{~cm}^{-1}$.

${ }^{1} \mathrm{H} \mathrm{NMR}\left(400 \mathrm{MHz}, \mathrm{CDCl}_{3}\right): \delta=16.88(\mathrm{~s}, 1 \mathrm{H}), 5.08(\mathrm{t}, J=2.2 \mathrm{~Hz}, 1 \mathrm{H}), 5.01$ $(\mathrm{t}, J=1.9 \mathrm{~Hz}, 1 \mathrm{H}), 2.83(\mathrm{t}, J=2.0 \mathrm{~Hz}, 2 \mathrm{H}), 2.21(\mathrm{~s}, 6 \mathrm{H}), 2.06(\mathrm{~s}, 6 \mathrm{H}), 1.64(\mathrm{~s}$, $3 \mathrm{H})$.

${ }^{13} \mathrm{C}$ NMR $\left(100 \mathrm{MHz}, \mathrm{CDCl}_{3}\right): \delta=207.1,192.3,144.5,114.5,106.0,71.0$, $30.7,26.9,22.7,18.9$.

HRMS (ESI): $m / z$ [M+H] ${ }^{+}$calcd for $\mathrm{C}_{14} \mathrm{H}_{20} \mathrm{O}_{4}: 253.1456$; found: 253.1442 .

6-Acetyl-3-benzoyl-3,6-dimethyl-4-methyleneoctane-2,7-dione (23n): $: 21$

Following method B, carbonate $\mathbf{1 4}^{21}(61.9 \mathrm{mg}, 0.24 \mathrm{mmol}$ ) was reacted with 3-methyl-2,4-pentanedione (28 $\mu \mathrm{L}, 0.24 \mathrm{mmol})$. Flash column chromatography [Petrol:EtOAc 4:1] afforded an inseparable mixture of 23n and homo-coupled 14 in a 5.3:1 ratio $(61 \mathrm{mg}$, corresponding to 50 $\mathrm{mg}$ of $23 \mathrm{n}, 63 \%$ ) as a red solid. $R_{F} 0.26$ [Petrol:Et0Ac 4:1]; m.p. $73-76^{\circ} \mathrm{C}$.

Enantioselective catalysis: carbonate $\mathbf{1 4}^{21}(45.8 \mathrm{mg}, 0.16 \mathrm{mmol})$, $\mathrm{Pd}_{2}(\mathrm{dba})_{3}(7.3 \mathrm{mg}, 0.008 \mathrm{mmol}),(R)$-Xylyl-P-PHOS (35, $7.3 \mathrm{mg}, 0.0096$ $\mathrm{mmol})$ and 3-methyl-2,4-pentanedione (19 $\mu \mathrm{L}, 0.16 \mathrm{mmol})$ were added to a dried tube under argon. The tube was fitted with a septum and purged further with argon. Tetrahydrofuran $(1 \mathrm{~mL})$ was added and the mixture was stirred at $60{ }^{\circ} \mathrm{C}$ for 2 hours, then concentrated in vacuo. Flash column chromatography [Petrol:EtOAc 9:1-4:1] afforded 23n (18 $\mathrm{mg}, 34 \%)$.

Chiral HPLC: OD-H column, $1 \mathrm{~mL} / \mathrm{min}$, [Hexane:IPA 9:1], $t_{\mathrm{A}}$ (major) $=7.7$ $\min , t_{\mathrm{B}}(\operatorname{minor})=8.5 \mathrm{~min}, 19 \%$ ee.

$[\alpha]_{\mathrm{D}}^{25}+1.3\left(\right.$ c $0.1, \mathrm{CHCl}_{3}, 19 \%$ ee) .

Ethyl 3,3,6-triacetyl-6-methyl-4-methylene-7-oxooctanoate (230):

Following method B, carbonate $\mathbf{1 4}^{15}(50 \mathrm{mg}, 0.24 \mathrm{mmol})$ was reacted with 3-methyl-2,4-pentanedione $(28 \mu \mathrm{L}, 0.24 \mathrm{mmol})$. Flash column chromatography [Petrol:EtOAc 4:1] afforded an inseparable mixture of 23o, homo-coupled 22, and the regioisomer of $23 \mathrm{o}$ in a 16:1.2:1 ratio (38 mg, corresponding to $33.5 \mathrm{mg}$ of $\mathbf{2 3 0}, 41 \%$ ) as a green oil. $R_{F} 0.31$ [Petrol:EtOAc 4:1].

IR (film): 2983, 2935, 1697, $1638 \mathrm{~cm}^{-1}$.

$\left.{ }^{1} \mathrm{H} \mathrm{NMR} \mathrm{(400} \mathrm{MHz,} \mathrm{CDCl}_{3}\right): \delta=5.09(\mathrm{q}, J=1.8 \mathrm{~Hz}, 1 \mathrm{H}), 4.87(\mathrm{q}, J=1.9 \mathrm{~Hz}$, $1 \mathrm{H}), 4.13(\mathrm{q}, J=4.1 \mathrm{~Hz}, 2 \mathrm{H}), 3.05(\mathrm{~s}, 2 \mathrm{H}), 2.54(\mathrm{t}, J=1.6 \mathrm{~Hz}, 2 \mathrm{H}), 2.25(\mathrm{~s}$, $6 \mathrm{H}), 2.11(\mathrm{~s}, 6 \mathrm{H}), 1.40(\mathrm{~s}, 3 \mathrm{H}), 1.25(\mathrm{t}, J=7.2 \mathrm{~Hz}, 3 \mathrm{H})$.

${ }^{13} \mathrm{C}$ NMR $\left(100 \mathrm{MHz}, \mathrm{CDCl}_{3}\right): \delta=206.4,204.8,170.6,140.2,117.2,73.5$, $65.3,61.2,37.7,36.0,28.1,26.2,18.0,14.0$.

HRMS (ESI): $m / z \quad[M+N a]^{+}$calcd for $\mathrm{C}_{18} \mathrm{H}_{26} \mathrm{O}_{6}: 361.1622$; found: 361.1606.

2-(4-Acetyl-4-methyl-5-oxohex-1-en-2-yl)-2-methylcyclohexane1,3-dione (23q):

Following method B, carbonate $\mathbf{1 4}^{15}(50 \mathrm{mg}, 0.24 \mathrm{mmol})$ was reacted with 3-methyl-2,4-pentanedione (28 $\mu \mathrm{L}, 0.24 \mathrm{mmol}$ ). Flash column chromatography [Petrol:EtOAc 9:1-4:1] afforded 23q (29 mg, 43\%) as a yellow solid. $R_{F} 0.31$ [Petrol:EtOAc 4:1]; m.p. $42-44{ }^{\circ} \mathrm{C}$.

IR (film): 3382, 2994, 2950, 2942, 1722, 1692, $1634 \mathrm{~cm}^{-1}$. 
${ }^{1} \mathrm{H}$ NMR (400 MHz, $\left.\mathrm{CDCl}_{3}\right): \delta=4.89(\mathrm{q}, J=1.7 \mathrm{~Hz}, 1 \mathrm{H}), 4.73(\mathrm{q}, J=1.7 \mathrm{~Hz}$, $1 \mathrm{H}), 2.85-2.74(\mathrm{~m}, 2 \mathrm{H}), 2.62-2.53(\mathrm{~m}, 2 \mathrm{H}), 2.47(\mathrm{t}, J=1.2 \mathrm{~Hz}, 2 \mathrm{H}), 2.15-$ $2.12(\mathrm{~m}, 1 \mathrm{H}), 2.10(\mathrm{~s}, 6 \mathrm{H}), 1.83-1.80(\mathrm{~m}, 1 \mathrm{H}), 1.42(\mathrm{~s}, 3 \mathrm{H}), 1.31(\mathrm{~s}, 3 \mathrm{H})$.

${ }^{13} \mathrm{C}$ NMR $\left(100 \mathrm{MHz}, \mathrm{CDCl}_{3}\right): \delta=208.0,206.6,142.8,114.8,73.2,65.9$, $38.5,36.2,26.2,18.9,18.2,17.4$.

HRMS (ESI): $m / z$ [M+H] ${ }^{+}$calcd for $\mathrm{C}_{16} \mathrm{H}_{22} \mathrm{O}_{4}: 279.1591$; found: 279.1585 .

Ethyl 2,5-diacetyl-2,5-dimethyl-4-methylene-6-oxoheptanoate (23s):

Following method B, carbonate $\mathbf{1 4}^{21}(47.1 \mathrm{mg}, 0.24 \mathrm{mmol})$ was reacted with ethyl 2-methyl acetoacetate (34 $\mu \mathrm{L}, 0.24 \mathrm{mmol})$. Flash column chromatography [Petrol:EtOAc 9:1-4:1] afforded 23s (27 mg, 38\%) as a brown oil. $R_{F} 0.29$ [Petrol:EtOAc 4:1].

IR (film): 2983, 2931, 1701, $1653 \mathrm{~cm}^{-1}$.

${ }^{1} \mathrm{H}$ NMR (400 MHz, CDCl 3$): \delta=5.01-4.99(\mathrm{~m}, 2 \mathrm{H}), 4.18(\mathrm{q}, J=7.1 \mathrm{~Hz}, 1 \mathrm{H})$, $4.18(\mathrm{q}, J=7.1 \mathrm{~Hz}, 1 \mathrm{H}), 2.69(\mathrm{dt}, J=18.1,1.8 \mathrm{~Hz}, 1 \mathrm{H}), 2.49(\mathrm{dt}, J=17.7,1.5$ $\mathrm{Hz}, 1 \mathrm{H}), 2.19$ (s, 3H), $2.11(\mathrm{~s}, 3 \mathrm{H}), 2.10(\mathrm{~s}, 3 \mathrm{H}), 1.43(\mathrm{~s}, 3 \mathrm{H}), 1.39(\mathrm{~s}, 3 \mathrm{H})$, $1.19(\mathrm{t}, J=7.2 \mathrm{~Hz}, 3 \mathrm{H})$.

${ }^{13} \mathrm{C}$ NMR $\left(100 \mathrm{MHz} \mathrm{CDCl}_{3}\right): \delta=207.2,207.1,205.0,172.7,142.4,116.0$, $72.0,61.8,58.7,36.2,27.3,27.0,26.0,19.0,18.6,13.9$.

HRMS (ESI): $m / z$ [M+H] ${ }^{+}$calcd for $\mathrm{C}_{16} \mathrm{H}_{24} \mathrm{O}_{5}: 297.1697$; found: 297.1684 .

3-(3-(3-Acetyl-2-oxotetrahydrofuran-3-yl)prop-1-en-2-yl)-3methylpentane-2,4-dione $(23 w)$ :

Following method B, carbonate $\mathbf{1 4}^{21}(47.1 \mathrm{mg}, 0.24 \mathrm{mmol})$ was reacted with $\alpha$-acetylbutyrolactone (30.8 $\mathrm{mg}, 0.24 \mathrm{mmol}$ ). Flash column chromatography [Petrol:EtOAc 9:1-4:1] afforded an inseparable mixture of 23w, homo-coupled 14 and homo-coupled 22 in a 6.8:2.2:1 ratio (35 $\mathrm{mg}$, corresponding to $23.0 \mathrm{mg}$ of $23 \mathrm{w}, 34 \%$ ) as a yellow oil. $R_{F} 0.15$ [Petrol:EtOAc 4:1].

IR (film): 2981, 2924, 2855, 1759, $1701 \mathrm{~cm}^{-1}$.

${ }^{1} \mathrm{H}$ NMR (300 MHz, $\left.\mathrm{CDCl}_{3}\right): \delta=5.02(\mathrm{q}, J=1.4 \mathrm{~Hz}, 1 \mathrm{H}), 4.89(\mathrm{q}, J=1.8 \mathrm{~Hz}$, $1 \mathrm{H}), 4.38-4.24(\mathrm{~m}, 2 \mathrm{H}), 3.13-3.00(\mathrm{~m}, 2 \mathrm{H}), 3.01(\mathrm{dt}, J=18.2,1.6 \mathrm{~Hz}, 1 \mathrm{H})$, 2.43-2.33 (m, 1H), $2.36(\mathrm{~s}, 3 \mathrm{H}), 2.17(\mathrm{~s}, 3 \mathrm{H}), 2.16(\mathrm{~s}, 3 \mathrm{H}), 1.59(\mathrm{~s}, 3 \mathrm{H})$.

${ }^{13} \mathrm{C}$ NMR $\left(75 \mathrm{MHz}, \mathrm{CDCl}_{3}\right): \delta=206.6,206.4,203.3,174.7,142.1,115.6$, $71.5,66.9,60.5,37.7,29.7,27.0,27.0,25.7,18.9$.

HRMS (ESI): $m / z$ [M+H] ${ }^{+}$calcd for $\mathrm{C}_{15} \mathrm{H}_{20} \mathrm{O}_{5}$ : 281.1384; found: 281.1348 .<smiles>C#CCOC(=O)O/C(C)=C(\C)C(=O)OCC</smiles>

Ethyl 2-methyl-3-((prop-2-ynyloxy)carbonyloxy)but-2-enoate (44):

A suspension of sodium hydride (60 wt\% in mineral oil, $92.3 \mathrm{mg}, 2.31$ mmol) in tetrahydrofuran $(10 \mathrm{~mL})$ was cooled to $0{ }^{\circ} \mathrm{C}$. A solution of 2 methyl ethyl acetoacetate $(300 \mu \mathrm{L}, 2.1 \mathrm{mmol})$ in tetrahydrofuran $(5 \mathrm{~mL})$ was added dropwise and the mixture was stirred at $0{ }^{\circ} \mathrm{C}$ for 10 minutes. Propargyl chloroformate (225 $\mu \mathrm{L}, 2.31 \mathrm{mmol})$ was added dropwise and the mixture was allowed to warm to room temperature and was stirred at room temperature for 1.5 hours. The reaction was quenched by the addition of aq. $\mathrm{HCl}(1 \mathrm{~N}, 20 \mathrm{~mL})$ and the mixture was extracted with EtOAc ( $3 \times 15 \mathrm{~mL})$. The combined organic phases were washed with brine $(20 \mathrm{~mL})$, dried $\left(\mathrm{MgSO}_{4}\right)$ and concentrated in vacuo. Flash column chromatography [Petrol:EtOAc 19:1] afforded 44 (200 mg, 45\%) as a clear oil. $R_{F} 0.65$ [Petrol:Et0Ac 7:1].

IR (film): 3368, 2939, 2122, 1723, 1686, $1638 \mathrm{~cm}^{-1}$.

${ }^{1} \mathrm{H}$ NMR (400 MHz, $\left.\mathrm{CDCl}_{3}\right): \delta=4.79(\mathrm{~d}, J=2.4 \mathrm{~Hz}, 2 \mathrm{H}), 4.18(\mathrm{q}, J=7.3 \mathrm{~Hz}$, $2 \mathrm{H}), 2.55(\mathrm{t}, J=2.4 \mathrm{~Hz}, 1 \mathrm{H}), 2.05(\mathrm{q}, J=1.2 \mathrm{~Hz}, 3 \mathrm{H}), 1.90(\mathrm{q}, J=1.2 \mathrm{~Hz}$, $3 \mathrm{H}), 1.27(\mathrm{t}, J=6.8 \mathrm{~Hz}, 3 \mathrm{H})$.

${ }^{13} \mathrm{C}$ NMR $\left(100 \mathrm{MHz} \mathrm{CDCl}_{3}\right): \delta=166.2,152.1,151.3,117.0,76.6,76.0$, $60.9,55.8,18.1,14.5,14.0$.

HRMS (ESI): $m / z$ [M+H] ${ }^{+}$calcd for $\mathrm{C}_{11} \mathrm{H}_{14} \mathrm{O}_{5}: 227.0914$; found: 227.0916 .
Ethyl

(23x):

2,5-diacetyl-2,5-dimethyl-3-methylene-6-oxoheptanoate

Following method B, carbonate $44(54.3 \mathrm{mg}, 0.24 \mathrm{mmol})$ was reacted with 3-methyl-2,4-pentanedione (28 $\mu \mathrm{L}, 0.24 \mathrm{mmol}$ ). Flash column chromatography [Petrol:EtOAc 9:1-4:1] afforded an inseparable mixture of $23 x$, homo-coupled 22 and homo-coupled 14 in a 16:1.3:1 ratio (34 $\mathrm{mg}$, corresponding to $30 \mathrm{mg}$ of $\mathbf{2 3 x}, 42 \%$ ) as a yellow oil. $R_{F} 0.35$ [Petrol:EtOAc 4:1].

IR (film): 2935, 2873, 1694, 1641, $1556 \mathrm{~cm}^{-1}$.

${ }^{1} \mathrm{H}$ NMR (400 MHz, $\left.\mathrm{CDCl}_{3}\right): \delta=5.00(\mathrm{q}, J=1.2 \mathrm{~Hz}, 1 \mathrm{H}), 4.76(\mathrm{q}, J=1.4 \mathrm{~Hz}$, $1 \mathrm{H}), 4.21(\mathrm{q}, J=7.1 \mathrm{~Hz}, 2 \mathrm{H}), 2.70(\mathrm{~d}, J=6.2 \mathrm{~Hz}, 2 \mathrm{H}), 2.21(\mathrm{~s}, 3 \mathrm{H}), 2.13(\mathrm{~s}$, $3 \mathrm{H}), 2.12(\mathrm{~s}, 3 \mathrm{H}), 1.55(\mathrm{~s}, 3 \mathrm{H}), 1.43(\mathrm{~s}, 3 \mathrm{H}), 1.27(\mathrm{t}, J=7.1 \mathrm{~Hz}, 3 \mathrm{H})$.

${ }^{13} \mathrm{C}$ NMR $\left(100 \mathrm{MHz}, \mathrm{CDCl}_{3}\right): \delta=207.1,206.9,204.8,171.4,142.0,114.7$, $66.4,66.3,61.6,36.1,27.0,26.3,26.2,19.9,17.8,14.0$.

HRMS (ESI): $m / z \quad[\mathrm{M}+\mathrm{Na}]^{+}$calcd for $\mathrm{C}_{16} \mathrm{H}_{24} \mathrm{O}_{5}: 319.1516$; found: 319.1524 .

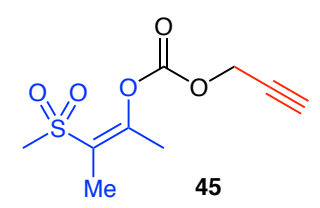

3-(Methylsulfonyl)but-2-en-2-yl prop-2-ynyl carbonate (45):

A suspension of sodium hydride (60 wt\% in mineral oil, $30.4 \mathrm{mg}, 0.76$ $\mathrm{mmol})$ in tetrahydrofuran $(30 \mathrm{~mL})$ was cooled to $0{ }^{\circ} \mathrm{C}$. A solution of 3(methylsulfonyl)butan-2-one ${ }^{25}(104 \mathrm{mg}, 0.69 \mathrm{mmol})$ in tetrahydrofuran $(5 \mathrm{~mL})$ was added dropwise and the mixture was stirred at $0{ }^{\circ} \mathrm{C}$ for 10 minutes. Propargyl chloroformate $(74 \mu \mathrm{L}, 0.76 \mathrm{mmol})$ was added dropwise and the mixture allowed to warm to room temperature and was stirred at room temperature for 1.5 hours. The reaction was quenched by the addition of aq. $\mathrm{HCl}(1 \mathrm{~N}, 10 \mathrm{~mL})$ and the mixture was extracted with EtOAc ( $3 \times 10 \mathrm{~mL})$. The combined organic phases were washed with brine $(10 \mathrm{~mL})$, dried $\left(\mathrm{MgSO}_{4}\right)$ and concentrated in vacuo. Flash column chromatography [Petrol:EtOAc 4:1-1:1] afforded 45 (101 $\mathrm{mg}, 64 \%$ ) as a white solid. $R_{F} 0.10$ [Petrol:EtOAc $\left.1: 1\right]$; m.p. $75-77^{\circ} \mathrm{C}$.

IR (film): 3293, 2929, 2137, 1763, $1668 \mathrm{~cm}^{-1}$.

${ }^{1} \mathrm{H}$ NMR (300 MHz, $\left.\mathrm{CDCl}_{3}\right): \delta=4.78(\mathrm{~d}, J=2.7 \mathrm{~Hz}, 2 \mathrm{H}), 2.99(\mathrm{~s}, 3 \mathrm{H}), 2.58$ $(\mathrm{t}, J=2.3 \mathrm{~Hz}, 1 \mathrm{H}), 2.13(\mathrm{q}, J=1.2 \mathrm{~Hz}, 3 \mathrm{H}), 2.03(\mathrm{q}, J=1.7 \mathrm{~Hz}, 3 \mathrm{H})$.

${ }^{13} \mathrm{C}$ NMR $\left(75 \mathrm{MHz}, \mathrm{CDCl}_{3}\right): \delta=152.7,150.8,127.7,76.4,76.0,56.3,42.6$, $18.3,13.5$.

HRMS (ESI): $m / z[\mathrm{M}+\mathrm{Na}]^{+}$calcd for $\mathrm{C}_{9} \mathrm{H}_{12} \mathrm{SO}_{5}$ : 255.0298; found: 255.0291

6-Acetyl-3,6-dimethyl-4-methylene-3-(methylsulfonyl)octane-2,7dione (23y):

Following method B, carbonate $45(55.7 \mathrm{mg}, 0.24 \mathrm{mmol})$ was reacted with 3-methyl-2,4-pentanedione (28 $\mu \mathrm{L}, 0.24 \mathrm{mmol}$ ). Flash column chromatography [Petrol:EtOAc 9:1-1:1] afforded 23y (15 mg, 21\%) as a green oil. $R_{F} 0.10$ [Petrol:EtOAc 4:1].

IR (film): 2927, 2855, 1712, 1695, $1634 \mathrm{~cm}^{-1}$.

${ }^{1} \mathrm{H} \mathrm{NMR}\left(400 \mathrm{MHz}, \mathrm{CDCl}_{3}\right): \delta=5.23(\mathrm{q}, J=1.6 \mathrm{~Hz}, 1 \mathrm{H}), 5.07(\mathrm{q}, J=1.9 \mathrm{~Hz}$, $1 \mathrm{H}), 3.07(\mathrm{~s}, 3 \mathrm{H}), 2.96-2.94(\mathrm{~m}, 1 \mathrm{H}), 2.93-2.91(\mathrm{~m}, 1 \mathrm{H}), 2.25(\mathrm{~s}, 3 \mathrm{H}), 2.18$ $(\mathrm{s}, 3 \mathrm{H}), 2.17(\mathrm{~s}, 3 \mathrm{H}), 1.86(\mathrm{~s}, 3 \mathrm{H}), 1.48(\mathrm{~s}, 3 \mathrm{H})$.

${ }^{13} \mathrm{C}$ NMR $\left(100 \mathrm{MHz}, \mathrm{CDCl}_{3}\right): \delta=207.1,207.0,202.7,137.2,121.1,80.2$, $65.7,37.8,35.7,27.2,26.7,26.2,18.9,15.6$.

LRMS (ESI): $m / z$ [M+H] ${ }^{+}$calcd for $\mathrm{C}_{14} \mathrm{H}_{22} \mathrm{SO}_{5}$ : 303.1261 ; found: 303.0790 .

Methyl 1-(2-(1-acetyl-2-oxocyclohexyl)allyl)-1H-pyrrole-2carboxylate $(24 \mathrm{~g}): 22$

Following method C, carbonate $\mathbf{3 1}^{15}$ (53 mg, $0.24 \mathrm{mmol}$ ) was reacted with methyl- $1 H$-pyrrole-2-carboxylate ( $30 \mathrm{mg}, 0.24 \mathrm{mmol}$ ). Flash column chromatography [Petrol:EtOAc 9:1-4:1] afforded $\mathbf{2 4 g}$ (59 $\mathrm{mg}, 81 \%$ ) as a yellow solid. $R_{F} 0.43$ [Petrol:EtOAc 4:1]; m.p. $104-106^{\circ} \mathrm{C}$. 
Enantioselective catalysis: carbonate $\mathbf{3 1}^{15}$ (35.5 mg, $0.16 \mathrm{mmol}$ ), $\mathrm{Pd}_{2}(\mathrm{dba})_{3}(7.3 \mathrm{mg}, 0.008 \mathrm{mmol}),(R)$-Xylyl-P-PHOS (35, $7.3 \mathrm{mg}, 0.0096$ mmol) and methyl- $1 H$-pyrrole-2-carboxylate $(20 \mathrm{mg}, 0.16 \mathrm{mmol}$ ) were added to a dried tube under argon. The tube was fitted with a septum and purged further with argon. Tetrahydrofuran $(1 \mathrm{~mL})$ was added and the mixture was stirred at $60^{\circ} \mathrm{C}$ for 2 hours, then concentrated in vacuo. Flash column chromatography [Petrol:EtOAc 9:1-4:1] afforded 24g (39 $\mathrm{mg}, 80 \%)$.

Chiral HPLC: OD-H column, $1 \mathrm{~mL} / \mathrm{min}$, [Hexane:IPA 19:1], $t_{\mathrm{A}}$ (minor) $=$ $8.7 \mathrm{~min}, t_{\mathrm{B}}$ (major) $=9.1 \mathrm{~min}, 19 \%$ ee.

$[\alpha]_{\mathrm{D}}{ }^{25}-0.5\left(c 0.1, \mathrm{CHCl}_{3}, 19 \%\right.$ ee $)$.

2-(1-Acetyl-2-oxocyclohexyl)allyl benzoate (25a) and 3-(1-acetyl-2oxocyclohexyl)prop-1-en-2-yl benzoate (26a):

Following method D, carbonate $\mathbf{3 1}(53.3 \mathrm{mg}, 0.24 \mathrm{mmol})$ was reacted with benzoic acid (29.3 mg, $0.24 \mathrm{mmol}$ ). Flash column chromatography [Petrol:EtOAc 19:1-9:1] afforded an inseparable mixture of 25a and 26a in a 1.7:1 ratio (32 mg, $44 \%$ ) as a clear oil. $R_{F} 0.26$ [Petrol:EtOAc 9:1]

IR (film): 2931, 2866, 17171, $1698 \mathrm{~cm}^{-1}$.

${ }^{1} \mathrm{H}$ NMR (400 $\mathrm{MHz} \mathrm{CDCl}_{3}$, isomer 26a annotated by an asterisk): $\delta=$ 8.03-7.92 (m, $2 \mathrm{H}$ and $\left.2 \mathrm{H}^{*}\right), 7.62-7.51\left(\mathrm{~m}, 1 \mathrm{H}\right.$ and $\left.1 \mathrm{H}^{*}\right), 7.50-7.38(\mathrm{~m}, 2 \mathrm{H}$ and $\left.2 \mathrm{H}^{*}\right), 5.67(\mathrm{~s}, 1 \mathrm{H}), 5.21(\mathrm{~s}, 1 \mathrm{H}), 4.96\left(\mathrm{~s}, 1 \mathrm{H}^{*}\right), 4.90\left(\mathrm{~s}, 1 \mathrm{H}^{*}\right), 4.89(\mathrm{~d}, J=$ $13.6 \mathrm{~Hz}, 1 \mathrm{H}), 4.83(\mathrm{~d}, J=13.6 \mathrm{~Hz}, 1 \mathrm{H}), 3.07$ (d, $\left.J=15.6 \mathrm{~Hz}, 1 \mathrm{H}^{*}\right), 2.76(\mathrm{~d}, J$ $\left.=15.2 \mathrm{~Hz}, 1 \mathrm{H}^{*}\right), 2.71-2.57\left(\mathrm{~m}, 1 \mathrm{H}\right.$ and $\left.1 \mathrm{H}^{*}\right), 2.54-2.34\left(\mathrm{~m}, 2 \mathrm{H}\right.$ and $\left.1 \mathrm{H}^{*}\right)$, $2.23(\mathrm{~s}, 3 \mathrm{H}), 2.22-2.08\left(\mathrm{~m}, 1 \mathrm{H}\right.$ and $\left.1 \mathrm{H}^{*}\right), 2.03\left(\mathrm{~s}, 3 \mathrm{H}^{*}\right), 2.03-1.93\left(\mathrm{~m}, 1 \mathrm{H}^{*}\right)$, 1.92-1.57 (m, $4 \mathrm{H}$ and $\left.3 \mathrm{H}^{*}\right), 1.56-1.43\left(\mathrm{~m}, 1 \mathrm{H}^{*}\right)$.

${ }^{13} \mathrm{C}$ NMR $\left(75 \mathrm{MHz} \mathrm{CDCl}_{3}\right.$ ): $\delta=209.2,208.4,206.5,204.6,165.9,164.4$, $151.4,141.4,133.5,133.2,129.9,129.6,129.5,129.3,128.5,128.4,120.0$, 106.4, 71.8, 66.6, 65.4, 41.6, 40.6, 38.8, 33.8, 32.3, 27.3, 27.1, 27.1, 26.4, $22.1,21.7$.

HRMS (ESI): $m / z$ [M+Na] $]^{+}$calcd for $\mathrm{C}_{18} \mathrm{H}_{20} \mathrm{O}_{4}$ : 323.1254; found: 323.1251.

2-(1-Acetyl-2-oxocyclohexyl)allyl pivalate (25b) and 3-(1-acetyl-2oxocyclohexyl)prop-1-en-2-yl pivalate (26b):

Following method D, carbonate $31(53.3 \mathrm{mg}, 0.24 \mathrm{mmol})$ was reacted with pivalic acid (24.5 $\mathrm{mg}, 0.24 \mathrm{mmol})$. Flash column chromatography [Petrol:EtOAc 19:1-9:1] afforded an inseparable mixture of $\mathbf{2 5} \mathbf{b}$ and $\mathbf{2 6} \mathbf{b}$ in a $1.7: 1$ ratio $(29 \mathrm{mg}, 43 \%)$ as clear oily crystals. $R_{F} 0.62$ [Petrol:EtOAc $4: 1]$.

\section{IR (film): 2956, 2874, 1732, 1717, $1696 \mathrm{~cm}^{-1}$.}

${ }^{1} \mathrm{H}$ NMR (300 MHz, $\mathrm{CDCl}_{3}$, isomer 26b annotated by an asterisk): $\delta=5.54$ $(\mathrm{s}, 1 \mathrm{H}), 5.14(\mathrm{~s}, 1 \mathrm{H}), 4.76\left(\mathrm{~d}, J=1.8 \mathrm{~Hz}, 1 \mathrm{H}^{*}\right), 4.73\left(\mathrm{~d}, J=1.5 \mathrm{~Hz}, 1 \mathrm{H}^{*}\right), 4.63$ (d, $J=13.5 \mathrm{~Hz}, 1 \mathrm{H}), 4.50(\mathrm{~d}, J=13.5 \mathrm{~Hz}, 1 \mathrm{H}), 2.81\left(\mathrm{~d}, J=15.3 \mathrm{~Hz}, 1 \mathrm{H}^{*}\right.$ ), $2.70\left(\mathrm{~d}, J=15.3 \mathrm{~Hz}, 1 \mathrm{H}^{*}\right), 2.67-2.21\left(\mathrm{~m}, 3 \mathrm{H}\right.$ and $\left.4 \mathrm{H}^{*}\right), 2.21(\mathrm{~s}, 3 \mathrm{H}), 2.10$ (s, $\left.3 \mathrm{H}^{*}\right), 2.09-1.92\left(\mathrm{~m}, 1 \mathrm{H}\right.$ and $\left.1 \mathrm{H}^{*}\right), 1.92-1.77(\mathrm{~m}, 2 \mathrm{H}), 1.77-1.57(\mathrm{~m}, 2 \mathrm{H}$ and $\left.3 \mathrm{H}^{*}\right), 1.20\left(\mathrm{~s}, 9 \mathrm{H}^{*}\right), 1.16(\mathrm{~s}, 9 \mathrm{H})$.

${ }^{13} \mathrm{C}$ NMR (75 MHz, $\left.\mathrm{CDCl}_{3}\right): \delta=209.3,208.4,206.3,204.7,177.9,176.5$, 151.8, 141.7, 120.8, 105.4, 71.6, 66.6, 65.2, 41.7, 40.5, 39.0, 38.7, 38.3, $33.7,32.0,27.5,27.2,27.0,27.0,26.9,26.5,22.1,21.6$.

HRMS (ESI): $m / z$ [M+Na] ${ }^{+}$calcd for $\mathrm{C}_{16} \mathrm{H}_{24} \mathrm{O}_{4}$ : 303.1567; found: 303.1558.

2-(2-(1-Acetyl-2-oxocyclohexyl)allyl) 1-(tert-butyl) (2S)pyrrolidine-1,2-dicarboxylate (25c) and 2-(3-(1-acetyl-2oxocyclohexyl)prop-1-en-2-yl) 1-(tert-butyl) (2S)-pyrrolidine-1,2dicarboxylate (26c):

Following method D, carbonate $\mathbf{3 1}(53.3 \mathrm{mg}, 0.24 \mathrm{mmol})$ was reacted with $N$-Boc-L-proline (52 mg, $0.24 \mathrm{mmol}$ ). Flash column chromatography [Petrol:EtOAc 9:1-4:1] afforded 25c (46 mg, 49\%) as a 1:1 mixture of diastereoisomers as a sticky pale yellow oil, $R_{F} 0.06$ [Petrol:EtOAc 9:1], and $26 \mathrm{c}(14 \mathrm{mg}, 15 \%)$ as a 1:1 mixture of diastereoisomers as a sticky pale yellow oil, $R_{F} 0.07$ [Petrol:EtOAc 9:1].

25c: IR (film): 2974, 1752, $1696 \mathrm{~cm}^{-1}$.

${ }^{1} \mathrm{H}$ NMR (400 MHz, $\mathrm{CDCl}_{3}$, mixture of diastereoisomers and rotamers): $\delta$ $=5.61-5.49(\mathrm{~m}, 1 \mathrm{H}), 5.19-5.10(\mathrm{~m}, 1 \mathrm{H}), 4.78-4.48(\mathrm{~m}, 2 \mathrm{H}), 4.39-4.15(\mathrm{~m}$,
1H), 3.60-3.30 (m, 2H), 2.68-2.52 (m, 1H), 2.52-2.40 (m, 1H), 2.40-2.29 (m, $1 \mathrm{H}), 2.27-2.09(\mathrm{~m}, 4 \mathrm{H}), 2.07-1.78(\mathrm{~m}, 6 \mathrm{H}), 1.78-1.61(\mathrm{~m}, 2 \mathrm{H}), 1.47-$ $1.40(\mathrm{~m}, 9 \mathrm{H})$.

${ }^{13} \mathrm{C}$ NMR (100 MHz, $\mathrm{CDCl}_{3}$, mixture of diastereoisomers and rotamers): $\delta$ $=209.3,209.2,209.0,208.9,206.7,206.4,206.4,172.4,172.4,172.3$, $171.0,170.9,154.3,154.3,153.7,153.6,141.4,141.3,141.1,141.0,120.0$, 119.8, 119.7, 119.2, 78.0, 79.8, 71.8, 71.7, 71.6, 59.1, 59.1, 59.0, 59.0, $58.9,58.8,46.6,46.3,40.8,40.6,40.6,32.5,32.3,32.0,30.8,30.7,30.7$, $29.8,29.7,28.4,28.3,27.4,27.2,27.1,27.1,27.1,27.0,27.0,24.4,24.4$, 24.3, 23.7, 23.6, 21.7, 21.6, 21.6.

HRMS (ESI): $m / z[\mathrm{M}+\mathrm{Na}]^{+}$calcd for $\mathrm{C}_{21} \mathrm{H}_{31} \mathrm{NO}_{6}$ : 416.2044; found: 416.2029.

26c: IR (film): 2942, 2874, 1760, $1696 \mathrm{~cm}^{-1}$.

${ }^{1} \mathrm{H}$ NMR (400 MHz, $\mathrm{CDCl}_{3}$, mixture of diastereoisomers and rotamers): $\delta$ $=4.99-4.91(\mathrm{~m}, 1 \mathrm{H}), 4.77(\mathrm{~s}, 1 \mathrm{H}), 4.29-4.14(\mathrm{~m}, 1 \mathrm{H}), 3.60-3.32(\mathrm{~m}, 2 \mathrm{H})$, 2.93-2.78 (m, 1H), 2.72-2.43 (m, 4H), 2.30-2.17 (m, 2H), 2.17-2.09 (m, $3 \mathrm{H}), 2.07-1.81(\mathrm{~m}, 4 \mathrm{H}), 1.81-1.57(\mathrm{~m}, 3 \mathrm{H}), 1.51-1.38(\mathrm{~m}, 9 \mathrm{H})$.

${ }^{13} \mathrm{C}$ NMR $\left(100 \mathrm{MHz}, \mathrm{CDCl}_{3}\right.$, mixture of diastereoisomers and rotamers): $\delta$ $=208.6,208.4,205.4,204.6,170.9,170.7,170.6,154.3,153.7,153.7$, 151.2, 151.1, 151.1, 105.6, 105.1, 105.1, 80.1, 79.8, 66.7, 66.6, 59.2, 59.2, $59.0,46.6,46.4,41.7,41.6,38.8,38.7,38.4,38.2,33.8,33.8,33.6,30.5$, $29.5,28.4,28.4,27.0,26.5,26.4,24.4,23.6,22.1$.

HRMS (ESI): $m / z[\mathrm{M}+\mathrm{Na}]^{+}$calcd for $\mathrm{C}_{21} \mathrm{H}_{31} \mathrm{NO}_{6}$ : 416.2044; found: 416.2045 .

3-(2-(1-Acetyl-2-oxocyclohexyl)allyl)-3-benzylpentane-2,4-dione (34a):

Enantioselective catalysis: carbonate $3^{15}(35.5 \mathrm{mg}, 0.16 \mathrm{mmol}$ ), $\mathrm{Pd}_{2}(\mathrm{dba})_{3}(7.3 \mathrm{mg}, 0.008 \mathrm{mmol}),(R)$-Xylyl-P-PHOS (35, $7.3 \mathrm{mg}, 0.0096$ $\mathrm{mmol}$ ) and 3-benzylpentane-2,4-dione (30.5 mg, $0.16 \mathrm{mmol}$ ) were added to a dried tube under argon. The tube was fitted with a septum and purged further with argon. Tetrahydrofuran (1 mL) was added and the mixture was stirred at $60{ }^{\circ} \mathrm{C}$ for 2 hours, then concentrated in vacuo. Flash column chromatography [Petrol:EtOAc 9:1-4:1] afforded 34a (17 $\mathrm{mg}, 29 \%$ ) as a clear oil. $R_{F} 0.44$ [Petrol:EtOAc 4:1].

Chiral HPLC: AD-H column, $1 \mathrm{~mL} / \mathrm{min}$, [Hexane:IPA 9:1], $t_{\mathrm{A}}($ minor $)=8.4$ $\min , t_{\mathrm{B}}$ (major) $=9.5 \mathrm{~min}, 19 \%$ ee.

$[\alpha]_{\mathrm{D}}{ }^{25}+1.0\left(c 0.1, \mathrm{CHCl}_{3}, 19 \% \mathrm{ee}\right)$.

IR (film): 2942, 2206, $1694 \mathrm{~cm}^{-1}$.

${ }^{1} \mathrm{H}$ NMR (400 MHz, $\left.\mathrm{CDCl}_{3}\right): \delta=7.25-7.19(\mathrm{~m}, 3 \mathrm{H}), 6.99-6.93(\mathrm{~m}, 2 \mathrm{H}), 5.04$ (q, $J=1.7 \mathrm{~Hz}, 1 \mathrm{H}), 4.97(\mathrm{q}, J=1.5 \mathrm{~Hz}, 1 \mathrm{H}), 3.40(\mathrm{dd}, J=19.3,15.0 \mathrm{~Hz}, 2 \mathrm{H})$, $2.56(\mathrm{dt}, J=19.1,1.6 \mathrm{~Hz}, 1 \mathrm{H}), 2.52-2.36(\mathrm{~m}, 3 \mathrm{H}), 2.24(\mathrm{~s}, 3 \mathrm{H}), 2.22(\mathrm{~s}, 3 \mathrm{H})$, 2.17-2.13 (m, 1H), $2.07(\mathrm{~s}, 3 \mathrm{H}), 2.07-2.00(\mathrm{~m}, 1 \mathrm{H}), 1.90-1.80(\mathrm{~m}, 1 \mathrm{H})$, $1.77-1.66(\mathrm{~m}, 1 \mathrm{H}), 1.57-1.46(\mathrm{~m}, 2 \mathrm{H})$.

${ }^{13} \mathrm{C}$ NMR $\left(100 \mathrm{MHz}, \mathrm{CDCl}_{3}\right): \delta=209.1,207.4,206.9,206.6,141.2,135.9$, 129.6, 128.4, 127.2, 115.8, 73.4, 70.2, 41.0, 38.0, 33.6, 33.0, 27.7, 27.4, $27.1,26.7,21.7$

HRMS (ESI): $m / z$ [M+H] ${ }^{+}$calcd for $\mathrm{C}_{23} \mathrm{H}_{28} \mathrm{O}_{4}: 369.2060$; found: 369.2050 .

Ethyl 3-(3-acetyl-3-methyl-2-methylene-4-oxopentyl)-4oxochroman-3- carboxylate (36a): ${ }^{21}$

Enantioselective catalysis: carbonate $\mathbf{1 4}^{21}(31.3 \mathrm{mg}, 0.16 \mathrm{mmol})$, $\mathrm{Pd}_{2}(\mathrm{dba})_{3}$ (7.3 mg, $\left.0.008 \mathrm{mmol}\right),(R)$-Tol-BINAP (37, $6.5 \mathrm{mg}, 0.0096$ $\mathrm{mmol}$ ) and ethyl 4-oxochroman-3-carboxylate ${ }^{26}(35 \mathrm{mg}, 0.16 \mathrm{mmol})$ were added to a dried tube under argon. The tube was fitted with a septum and purged further with argon. 1,4-Dioxane (1 mL) was added and the mixture was stirred at room temperature for 16 hours, then concentrated in vacuo. Flash column chromatography [Petrol:EtOAc 9:14:1] afforded 36a (21 mg, 35\%). $R_{F} 0.42$ [Petrol:EtOAc 5:1].

Chiral HPLC: OD-H column, $1 \mathrm{~mL} / \mathrm{min}$, [Hexane:IPA 9:1], $t_{\mathrm{A}}$ (major) = $10.1 \mathrm{~min}, t_{\mathrm{B}}$ (minor) $=11.2 \mathrm{~min}, 11 \%$ ee.

$[\alpha]_{\mathrm{D}}^{25}+0.8\left(c 0.1, \mathrm{CHCl}_{3}, 11 \%\right.$ ee $)$.

\section{Funding Information}


We gratefully acknowledge the Royal Society (RG150189, V.F.), the University of York (N.J.T. and V.F.), Lancaster University (M.K. and V.F.), the EU (Erasmus Exchange Programme to S.P.S.), and the Royal Society of Chemistry (Undergraduate Research Bursaries to P.J. and D.J.K.) for financial support

\section{Acknowledgment}

We are grateful to Prof Richard Taylor for the generous donation of chemicals and consumables as well as useful discussions. We thank Dr K. Heaton (University of York), Dr D. Rochester (Lancaster University), as well as the EPSRC Mass Spectrometry Service (Swansea, UK) for mass measurements. We also gratefully acknowledge $\mathrm{Dr} \mathrm{D}$. Rochester (Lancaster University) for help with HPLC analysis.

\section{Supporting Information}

Yes

\section{Primary Data}

No

\section{References}

(1) Hann, M. M. Med. Chem. Commun. 2011, 2, 349.

(2) Ritchie, T. J.; Macdonald, S. J. F.; Young, R. J.; Pickett, S. D. Drug Discov. Today 2011, 16, 164.

(3) Lovering, F.; Bikker, J.; Humblet, C. J. Med. Chem. 2009, 52, 6752.

(4) Lovering, F. Med. Chem. Commun. 2013, 4, 515.

(5) Hall, R. J.; Mortenson, P. N.; Murray, C. W. Prog. Biophys. Mol. Biol. 2014, $116,82$.

(6) (a) Douglas, C. J.; Overman, L. E. Proc. Natl. Acad. Sci. U. S. A. 2004, 101, 5363. (b) Trost, B. M.; Van Vranken, D. L. Chem. Rev. 1996, 96, 395. (c) Weaver, J. D.; Recio III, A.; Grenning, A. J.; Tunge, J. A. Chem. Rev. 2011, 111, 1846. (d) Liu, Y. Y.; Han, S. J.; Liu, W. B.; Stoltz, B. M. Acc. Chem. Res. 2015, 48 740.

(7) (a) Ogoshi, S.; Tsutsumi, K.; Kurosawa, H. J. Organomet. Chem. 1995, 493, C19. (b) Baize, M. W.; Blosser, P. W.; Plantevin, V.; Schimpff, D. G.; Gallucci, J. C.; Wojcicki, A. Organometallics 1996, 15, 164. (c) Tsutsumi, K.; Ogoshi, S.; Nishiguchi, S.; Kurosawa, H. J. Am. Chem. Soc. 1998, 120, 1938. (d) Tsutsumi, K.; Kawase, T.; Kakiuchi, K.; Ogoshi, S.; Okada, Y.; Kurosawa, H. Bull. Chem. Soc. Jpn. 1999, 72, 2687.

(8) (a) Tsuji, J.; Mandai, T. Angew. Chem. Int. Ed. Engl. 1995, 34, 2589. (b) Ma, S. M. Eur. J. Org. Chem. 2004, 1175. (c) Behenna, D. C.; Mohr, J. T.; Sherden, N. H.; Marinescu, S. C.; Harned, A. M.; Tani, K.; Seto, M.; Ma, S.; Novak, Z.; Krout, M. R.; McFadden, R. M.; Roizen, J. L.; Enquist, J. A.; White, D. E.; Levine, S. R.; Petrova, K. V.; Iwashita, A.; Virgil, S. C.; Stoltz, B. M. Chem. Eur. J. 2011, 17, 14199. (d) Daniels, D. S. B.; Jones, A. S.; Thompson, A. L.; Paton, R. S.; Anderson, E. A. Angew. Chem. Int. Ed. 2014, 53, 1915.

(9) (a) Guo, L.-N.; Duan, X.-H.; Liang, Y.-M. Acc. Chem. Res. 2011, 44, 111. (b) Yoshida, M. Chem. Pharm. Bull. 2012, 60, 285. (c) Yoshida, M. Heterocycles 2013, 87, 1835. (d) Hu, X.-H.; Liu, Z.-T.; Shao, L.; Hu, X.-P. Synthesis 2015, 47, 913. (e) Franckevičius, V. Tetrahedron Lett. 2016, 57, 3586.
(10) (a) Tsuji, J.; Watanabe, H.; Minami, I.; Shimizu, I. J. Am. Chem. Soc. 1985, 107, 2196. (b) Geng, L.; Lu, X. Tetrahedron Lett. 1990, 31, 111. (c) Geng, L. F.; Lu, X. Y. J. Chem. Soc., Perkin Trans. 1 1992, 17. (d) Labrosse, J. R.; Lhoste, P.; Sinou, D. J. Org. Chem. 2001, 66, 6634.

(11) (a) Yoshida, M.; Fujita, M.; Ihara, M. Org. Lett. 2003, 5, 3325. (b) Casey, C. P.; Nash, J. R.; Yi, C. S.; Selmeczy, A. D.; Chung, S.; Powell, D. R.; Hayashi, R. K. J. Am. Chem. Soc. 1998, 120, 722. (c) Horino, Y.; Homura, N.; Inoue, K.; Yoshikawa, S. Adv. Synth. Catal. 2012, 354, 828.

(12) Nishioka, N.; Koizumi, T. Tetrahedron Lett. 2011, 52, 3662.

(13) (a) Duan, X.-H.; Guo, L.-N.; Bi, H.-P.; Liu, X.-Y.; Liang, Y.-M. Org. Lett. 2006, 8, 5777. (b) Guo, L.-N.; Duan, X.-H.; Bi, H.-P.; Liu, X.-Y.; Liang, Y.-M. J. Org. Chem. 2007, 72, 1538. (c) Bi, H.-P.; Guo, L.-N.; Gou, F.-R.; Duan, X.-H.; Liu, X.-Y.; Liang, Y.-M. J. Org. Chem. 2008, 73, 4713. (d) Yoshida, M.; Morishita, Y.; Fujita, M.; Ihara, M. Tetrahedron Lett. 2004, 45, 1861. (e) Yoshida, M.; Morishita, Y.; Fujita, M.; Ihara, M. Tetrahedron 2005, 61, 4381. (f) Nemoto, T.; Zhao, Z. D.; Yokosaka, T.; Suzuki, Y.; Wu, R.; Hamada, Y. Angew. Chem. Int. Ed. 2013, 52, 2217. (g) Iwata, A.; Inuki, S.; Oishi, S.; Fujii, N.; Ohno, H. Chem. Commun. 2014, $50,298$.

(14) (a) Yoshida, M.; Higuchi, M.; Shishido, K. Tetrahedron Lett. 2008, 49, 1678. (b) Yoshida, M.; Higuchi, M.; Shishido, K. Tetrahedron 2010, 66, 2675. (c) Yoshida, M.; Sugimura, C.; Shishido, K. Org. Lett. 2011, 13, 3482. (d) Montgomery, T. D.; Nibbs, A. E.; Zhu, Y.; Rawal, V. H. Org. Lett. 2014, 16, 3480. (15) Schröder, S. P.; Taylor, N. J.; Jackson, P.; Franckevičius, V. Org. Lett. 2013, 15, 3778.

(16) (a) Nibbs, A. E.; Montgomery, T. D.; Zhu, Y.; Rawal, V. H. J. Org. Chem. 2015, 80, 4928. (b) Gao, R.-D.; Liu, C.; Dai, L.-X.; Zhang, W.; You, S.-L. Org. Lett. 2014, 16, 3919.

(17) (a) Labrosse, J. R.; Lhoste, P.; Sinou, D. Org. Lett. 2000, 2, 527. (b) Damez, C.; Labrosse, J. R.; Lhoste, P.; Sinou, D. Tetrahedron Lett. 2003, 44, 557. (c) Dominczak, N.; Damez, C.; Rhers, B.; Labrosse, J.-R.; Lhoste, P.; Kryczka, B.; Sinou, D. Tetrahedron 2005, 61, 2589. (d) Yoshida, M.; Higuchi, M.; Shishido, K. Org. Lett. 2009, 11, 4752. (e) Labrosse, J.-R.; Lhoste, P.; Sinou, D. Eur. J. Org. Chem. 2002, 1966.

(18) Zhou, Y.; Zhu, F. L.; Liu, Z. T.; Zhou, X. M.; Hu, X. P. Org. Lett. 2016, 18, 2734.

(19) Bordwell, F. G. Acc. Chem. Res. 1988, 21, 456.

(20) Bordwell, F. G.; Branca, J. C.; Hughes, D. L.; Olmstead, W. N. J. Org. Chem. 1980, 45, 3305.

(21) Kenny, M.; Christensen, J.; Coles, S. J.; Franckevičius, V. Org. Lett. 2015, $17,3926$.

(22) Kenny, M.; Kitson, D. J.; Franckevičius, V. J. Org. Chem. 2016, 81, 5162.

(23) Matsuo, J. I.; Kawai, H.; Ishibashi, H. Tetrahedron Lett. 2007, 48, 3155.

(24) Jiang, Y. W.; Wu, N.; Wu, H. H.; He, M. Y. Synlett 2005, 2731.

(25) Alper, P.; Azimioara, M.; Cow, C.; Epple, R.; Lelais, G.; Mecom, J.; Mutnick, D.; Nikulin, V. WO 2011/014520.

(26) Hemavathi, S. N.; Naveen, C. R.; Rai, K. M. L. Indian J. Heterocycl. Chem. 2011, 20, 409 .

\section{Biosketches}




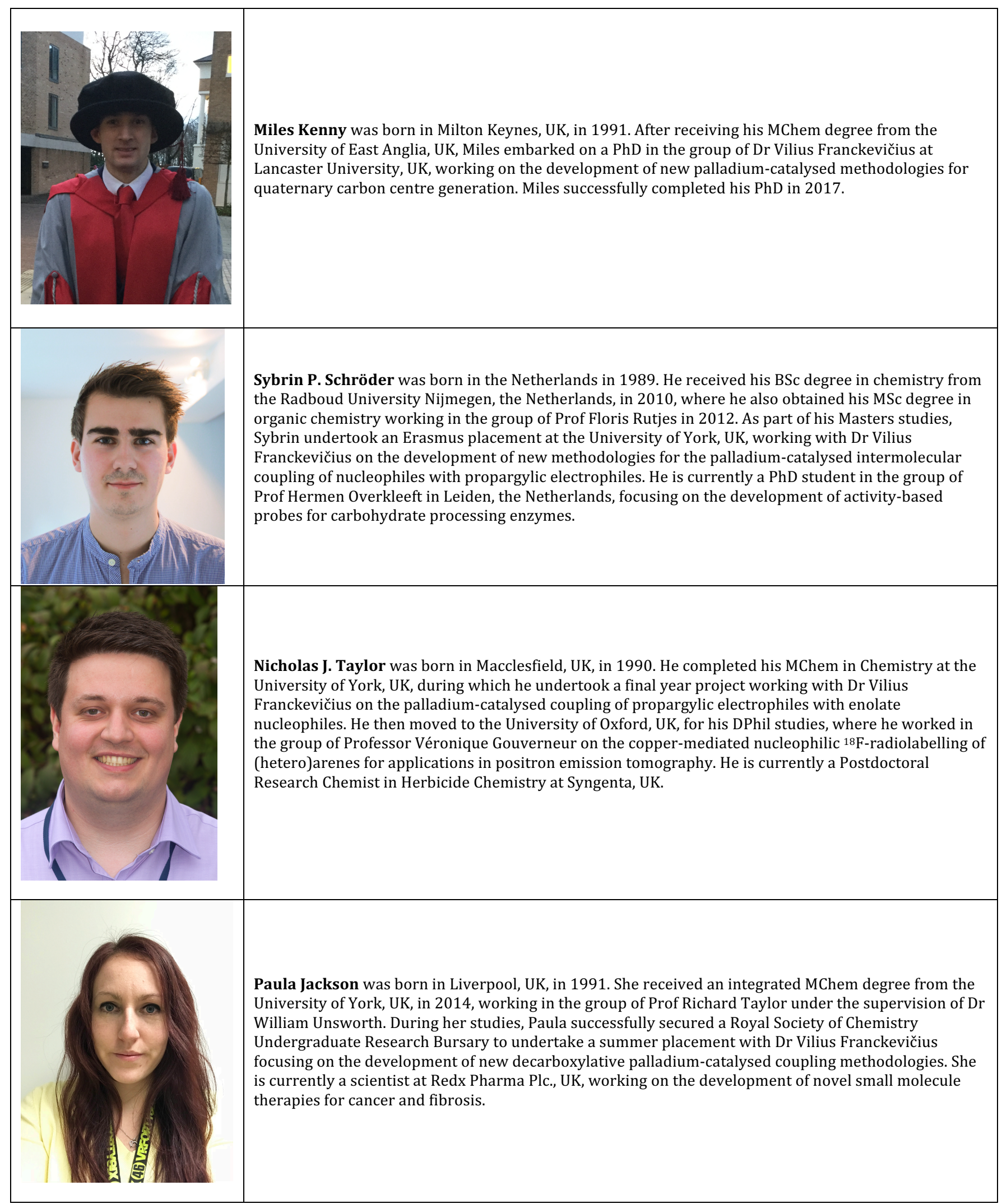




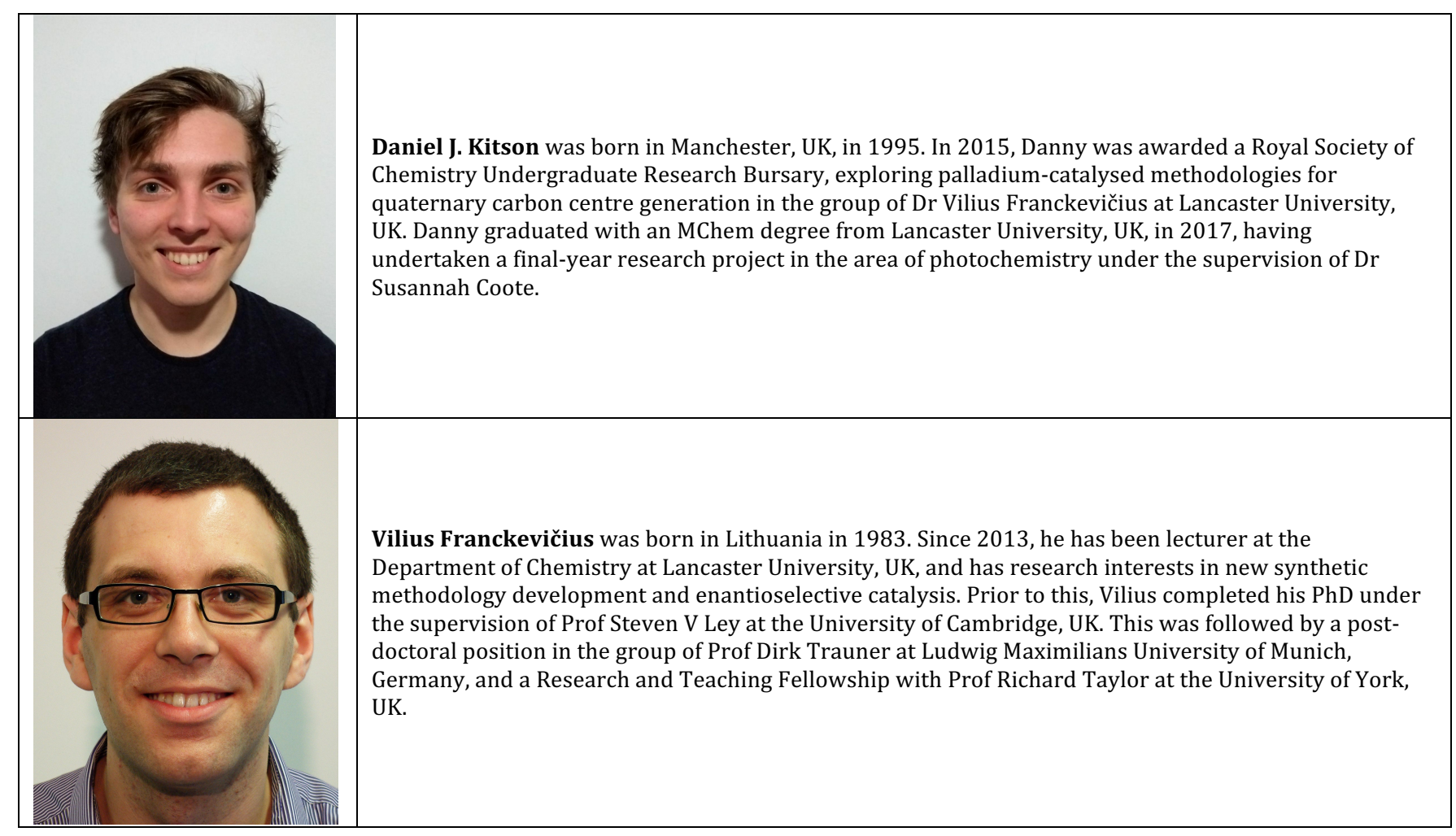

